\title{
Morpho-Structure of the 1982 Lava Flow Field at Mount Cameroon Volcano, West-Central Africa
}

\author{
M. N. Wantim ${ }^{1,2^{*}}$, M. Kervyn ${ }^{3}$, G. G. J. Ernst ${ }^{1}$, M.-A. Del Marmol ${ }^{1}$, C. E. Suh $^{2}$, P. Jacobs ${ }^{1}$ \\ ${ }^{1}$ Department of Geology and Soil Science, Ghent University, Ghent, Belgium \\ ${ }^{2}$ Department of Geology, University of Buea, South West Region, Buea, Cameroon \\ ${ }^{3}$ Department of Geography and Earth System Science, Vrije Universiteit Brussel, Brussels, Belgium \\ Email: *mabnechia@yahoo.com
}

Received December 10, 2012; revised January 14, 2013; accepted February 13, 2013

Copyright (C) 2013 M. N. Wantim et al. This is an open access article distributed under the Creative Commons Attribution License, which permits unrestricted use, distribution, and reproduction in any medium, provided the original work is properly cited.

\begin{abstract}
Basaltic eruptions have been observed to produce structurally complex, compound 'a'ā lava flow fields but their morphometry has only rarely been systematically documented. We document the morphology and structures that developed during the emplacement of the 1982 basaltic lava flow field at Mount Cameroon (MC) volcano over a period of one month. Topographic cross-sections (13 in total) were made from the main vent ( $2700 \mathrm{~m}$ above sea level (a.s.l)) down to a distance of $5.5 \mathrm{~km}$ on the cooled lava surface. Details obtained from these cross-sections include: channel width and depth, levee slope, lava surface morphology and structures. These details enabled us to describe the physical characteristics of the 1982 lava flow field. The inclined $\left(12^{\circ}-19^{\circ}\right)$ underlying slopes on which this flow field was emplaced resulted in a characteristic channelized basaltic 'a'a flow field morphology. This includes a proximal zone characterised by reduced flow width and depth with no subsidiary channels. Slab-crusted lava dominates the proximal channel distinctively bent into convex upward shapes. 7 secondary vents were observed for the first time $\sim 2.5 \mathrm{~km}$ from the main vent, with heights of $3-15 \mathrm{~m}$. This is a very significant observation since it points to the fact that the flow field emplacement may have been a product of 2 eruption sites as observed at other historical MC lava flow fields. This supposition was ruled out by further evidence obtained from other surface features within the flow field. The presence of these secondary vents still has an important bearing in lava flow hazard assessment. Field observations also revealed the presence of tumulus. This is a novel feature for MC lava flow fields. It displayed a close similarity to those observed at other basaltic volcanoes occurring in association with clinker 'a'à lava, lava tubes, squeeze-ups and pressure ridges. Channels are well-defined, bounded by levees. Accretional and overflow levees dominate in this flow field. This lava flow-field attained a final length of $7.5 \mathrm{~km}$, an area of $2.6 \times 10^{6} \mathrm{~m}^{2}$ and volume of $1.3 \times 10^{7} \mathrm{~m}^{3}$. The presence of tumulus indicates internal inflation together with structures such as pressure ridges and squeeze-ups which are also attributed to compressive forces. Our observations suggest that real-time monitoring of compound lava flow fields evolution at MC may reveal the emplacement mechanisms of complex structures such as the secondary vents ( $2180-2011 \mathrm{~m}$ a.s.l.) observed within the flow field. In addition, documenting the occurrence, morphology and link between lava tubes, tumulus and squeeze-ups may allow us to determine the risk of reactivation of a stalled flow front. This will thereby enhance the ability to track and assess hazards posed by lava flow emplacement from MC-like volcanoes.
\end{abstract}

Keywords: 1982 Eruption; Channels; Levees; Secondary Vents; Slope; Tumulus

\section{Introduction}

The advance of lava flows produced by volcanic eruptions has been studied through field observations [1-12]; remote sensing techniques [13-17], as well as through analytical or numerical modelling [18-23]. The above cited methods have greatly improved understanding of the emplacement dynamics of lava flows as they provide

${ }^{*}$ Corresponding author. clues about key processes occurring during eruptions even for flows not witnessed. However, the physical volcanology of most lava flow fields in developing countries has received limited systematic attention.

Lava morphological data are significant to understand lava emplacement mechanism and anticipate impacts from effusive eruptions. Lava flows can cover long distances in $3-6$ days, damaging properties and threatening lives $[2,24,25]$. The complex morphologies characteristic 
of long duration basaltic 'a'ā lava flow fields reflect the importance of processes such as inflation, formation of lava tubes and secondary vents [17]. The identification of secondary vent sites of lava flow fields is critical for lava flow hazard assessment [17]. They have been observed to allow flows to lengthen significantly over their forecasted cooling-limited lengths [26]. In contrast, overflow events or new lobes development favour flow field widening [27] instead of flow lengthening.

Advances in lava flow modelling in the past 25 years show that it is increasingly possible to anticipate the final lengths and spatial spread of single flow units $[18,28]$. However, during basaltic eruptions, complexities like new flow units are emplaced alongside and on top of earlier units resulting in compound flow fields [5,6]; channels crust over and lava tubes, secondary vents, squeeze-ups and tumulus develop. The development of these features hinders accurate modelling of long-lived ( $>1$ week) basaltic 'a'a lava flow fields [17] which is not accounted for in these models. To improve understanding on the development of compound lava flow fields and the dynamics of any volcanic system, it is recommended to quantify lava morpho-structures in detail both during and after emplacement [6,29].

Studies of terrestrial lavas suggest that the overall development of flow fields is systematic and that a general, normalized relationship can be established linking the final dimensions of a flow field to underlying slope, eruption duration, discharge rate, gravitational acceleration, lava density and rheology $[27,30,31]$. Linking qualitative and quantitative measurements of lava flow surface morphology with historical observations of eruptions is an important, but yet underexploited route, to constrain emplacement mechanism of basaltic lavas.

Basaltic lava flow fields often demonstrate compound morphology. That is they are comprised of several flow units and lobes with some superposed on each other [5, 17,32]). A flow lobe here refers to an individual package of lava surrounded by a chilled crust [1]. Compound here refers to a lava flow field made up of two or more flow lobes of any geometry or size $[1,33]$. The development of compound basaltic 'a'a lava flow fields is a common phenomena at Mount Cameroon (MC) volcano as exemplified in the 1959, 1982, and 1999 lava flow fields [2,8,34]. Most published data existing at MC (Figure 1) are limited to its seismicity, eruption dynamics, petrology and geochemistry of specific eruptions that occurred in the $20^{\text {th }}$ and $21^{\text {st }}$ centuries $[2,24,25,34-40]$. Recently, a few studies started focusing on lava flow morphology $[2,8,11]$ and hazards $[35,41-43]$ at MC.

Eruptions that produced basaltic lava flow fields from MC have been associated with significant impacts over the past years. The 1922, 1959 and 1999 eruptions posed major threats to agro-allied complexes and road infra- structure around the SW [24,25] and NE [2] flanks (Figure 1). Common phenomena observed for most historical eruptions at $\mathrm{MC}$ are that they are all fissure eruptions with venting typically at more than one site $(1922,1959$, 1999, 2000; Figure 2; $[2,8,11,24,25,40])$. Upper sites are dominated by more explosive activity building large pyroclastic cones, whereas lower sites emit the largest volume of lava. The principal lava type produced ranges from pahoehoe (ultra-proximal) to 'a'à (dominant flow morphology) and blocky lava observed at the distal end [11]. Petrographically, all these lavas are porphyritic $[2,25,39]$ with the exception of the 1982 lava that is nearly aphyric $[2,25,34]$.

In October 1982, an eruption that produced seismic swarms widely felt around Buea (SE flank; Figure 2), occurred on the SW flank of MC. The physical characteristics, composition and evolution of the 1982 lava flow field have been described by [34]. Other aspects including its petrology and geochemistry have been analysed by $[2,25,39]$. So far, no systematic field survey has been carried out on the 1982 flow field to document its morphology or quantify down channel geometry. Here, a systematic field study was carried out on the 1982 flow field with the primary objective of obtaining geometric parameters (width and depth) of the stable channel zone that fed the flow from source to the distal transitional-dispersed flow zone.

The goal of this paper is to describe the morphology and structures observed within the stable and transitional channel zones of the 1982 lava flow field as defined by [44]. Based on their observations of basaltic 'a'ā flow fields at Mauna Loa, Hawaii, [44] divided lava flow fields into four zones from vent to toe: 1) stable channel; 2) transitional channel; 3) dispersed flow zone and 4) flow toe. We present observations and field measurements made after the emplacement of this lava flow field, covering the proximal part fed principally from the source scoria cone (emplaced on characteristic slopes of $14^{\circ}$. $\left.18^{\circ}\right)$ and the transitional zone $\left(12^{\circ}-19^{\circ}\right)$.

The 1982-lava flow field offers an excellent opportunity to examine the large-scale structural evolution of a compound flow field as well as the complex surface features that are ubiquitous in most 'a'a flows. Such intermediate-long lived eruptions emplaced on inclined slopes offer good opportunities to investigate the effect of slope on 'a'à lava flow fields in terms of surface morphology and inferred emplacement. So far few studies have described long-lived basaltic lava flow field morphologies and emplacement processes on inclined [11,31] and extremely steep slopes [45]. Numerous studies however exist on the morphology of long-lived basaltic lava flow fields emplaced on flat to gently sloping surfaces [27], [46]. From this analysis, we document in detail the latestage development of this flow field which includes the 
formation of the secondary vents (short-lived ephemeral vents), lava tubes and tumulus and consider implications for lava flow hazard assessment. We also consider the role of effusion rate fluctuations for channel geometry fluctuation. Field measurements were used to constrain flow rheology. Such constraints are essential for a follow-up effort where lava flow hazard will be quantified.

\section{The Geology of Mount Cameroon and the 1982 Eruption Chronology}

\subsection{Geological Context of Mount Cameroon (MC)}

$\mathrm{MC}$ is the largest and most active of the continental volcanoes of the Cameroon Volcanic Line (CVL; Figure 1). The CVL is a major tectonic feature in West-Central Africa that runs SW-NE following a major left-lateral fault system that extends for more than $2000 \mathrm{~km}$, from Pagalu Island into West-Central Africa (Figure 1). The origin, geology, structure and petrology of the CVL have been discussed by several authors: [35,47-51]. The CVL's origin is still subjected to debate. The most widely accepted structural explanation for the origin of the CVL is that it is a product of Cretaceous reactivation of PanAfrican strike-slip faults trending N70E [38,48,52].

$\mathrm{MC}$ is a steep volcanic shield covered by successions of lava flows [11,53] and subsidiary scoriae deposits (Figure 2). It has a flat summit plateau, a rift zone defined by a linear cluster of eruptive vents, a deep valley (elephant valley) in the $\mathrm{N}$ flank, topographic steps at the base [53] together with numerous faults and fissures mostly trending N40E [35]. It is composed entirely of moderately alkaline basic lavas (alkaline basalts, hawaiites, picrites and mugearites $[35,48,49]$. Field observations indicate that lava flows are massive, porphyritic or vesicular. Moderately explosive Strombolian activity is common at high elevation vents [11,24,25], but lava flows are the most common products released from MC eruptions. Over historical times, most lava flow activity has

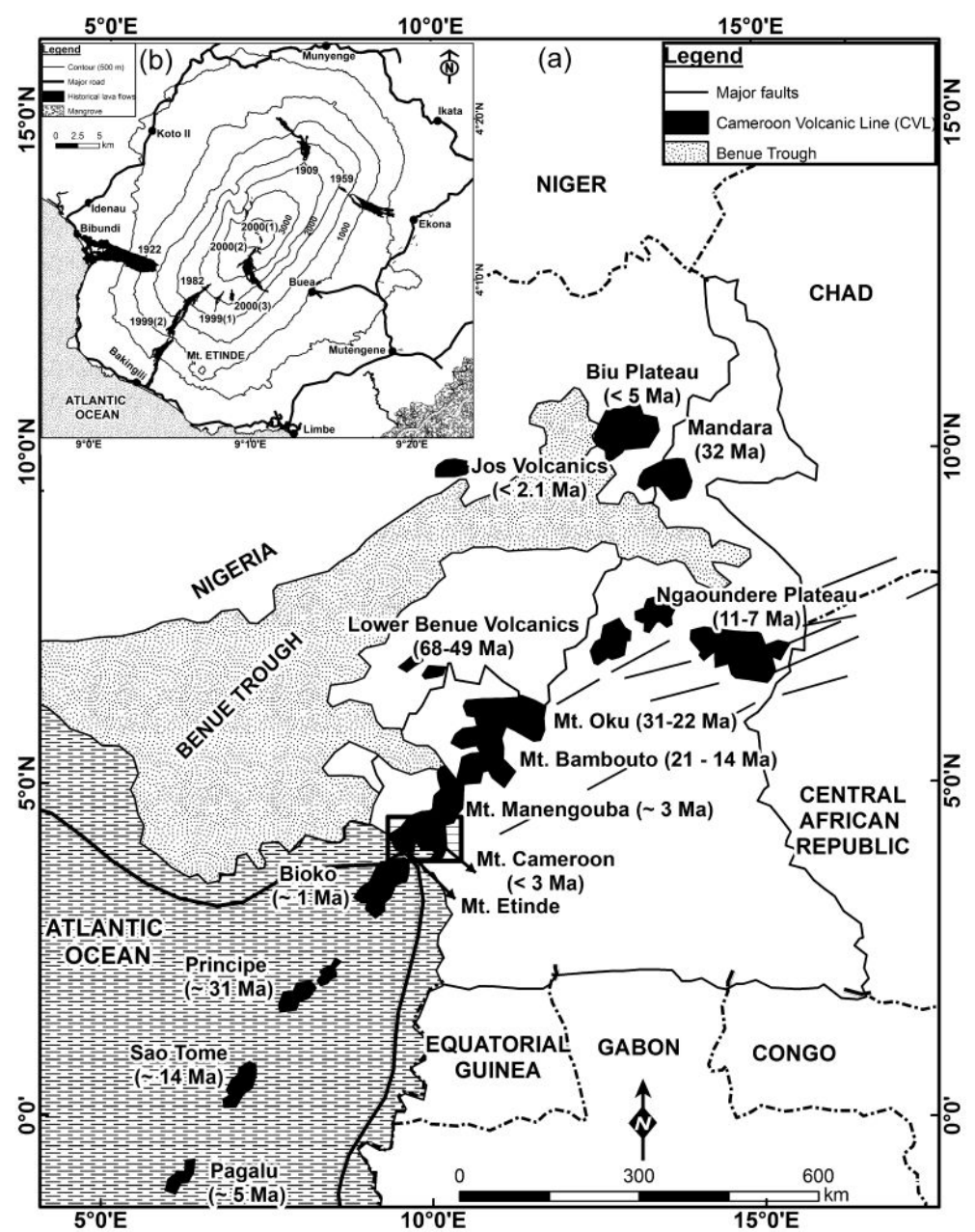

Figure 1. Sketch map of Cameroon showing Mount Cameroon and other volcanoes (both oceanic and continental sectors of the line) along the Cameroon Volcanic Line (CVL); Inset map of Mount Cameroon showing historical lava flows for the last 110 years. The reported ages for these volcanoes were obtained from Marzoli et al. (2000). 


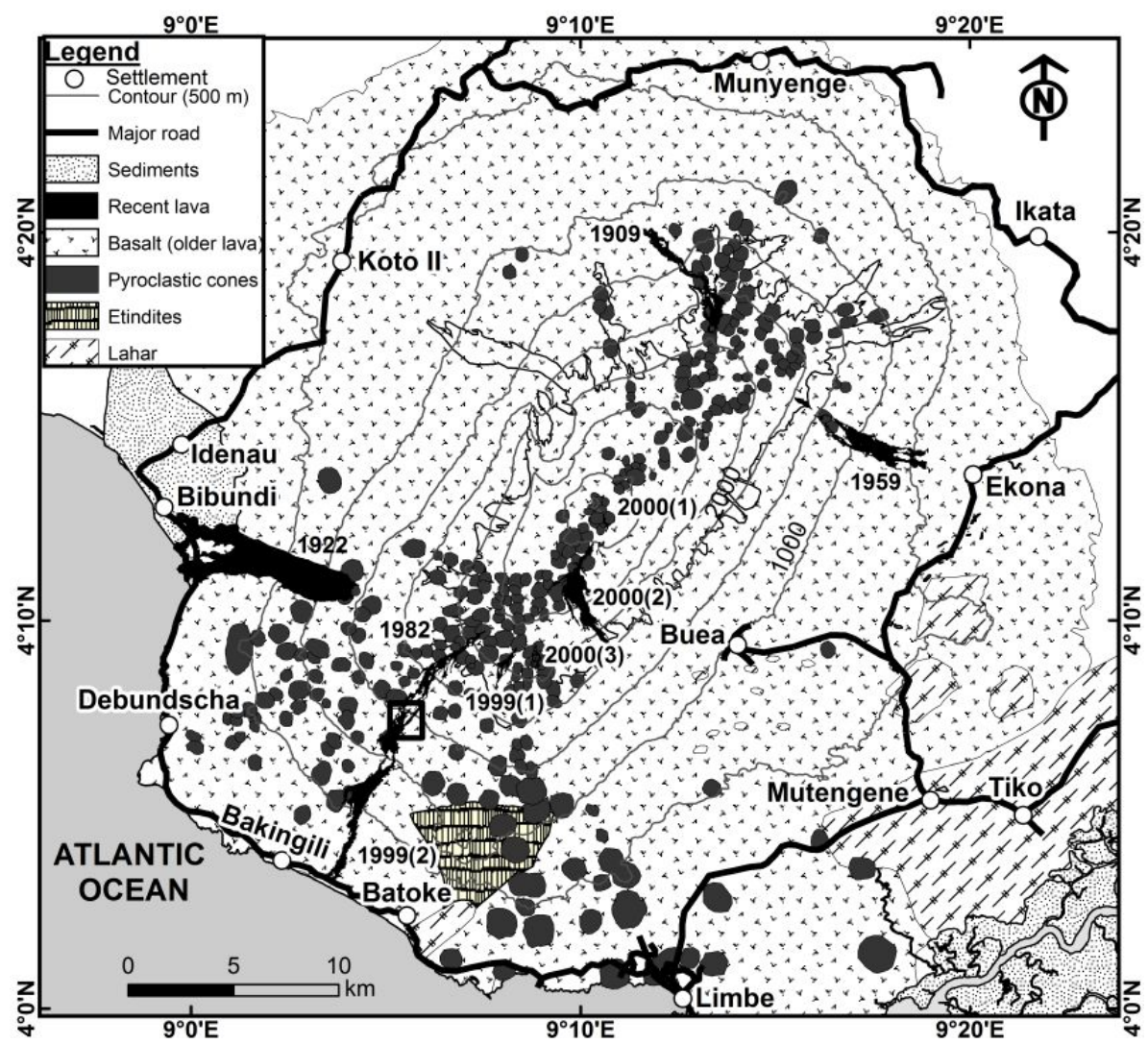

Figure 2. Map of the geology of Mount Cameroon and environs compiled from past dissertations. Pyroclastic cones and the historical lava flows indicated by their years with the numbers in bracket $(1,2,3)$ representing the different eruption sites were mapped from Digital Elevation Models (DEMs; 30 and $90 \mathrm{~m}$ ) and other satellite imagery (multispectral Landsat TM, ETM+ and ASTER scenes). The rectangle shows where the 1982 flow was buried by the lower 1999 vents and lava.

been confined to the summit, SW and NE flanks of MC (Figure 2). This has effectively protected the SE and NW flanks from lava inundation.

Historical lava flows have flow lengths from $\sim 850 \mathrm{~m}$ (upper 2000) to $11.5 \mathrm{~km}$ (1922, lower 1999; Figure 2; $[11,41])$. They cover an estimated surface area of 26.5 $\mathrm{km}^{2}$ in the last 110 years at MC (Figure 2). Observations of effusive events at the MC summit are extremely minor, characterised by flows with limited extents that stay within the confines of the crater (e.g. 2000 site 1 flow; Figure 2). In addition, vent types differ between minor and major effusive events. Minor effusive events are fed by persistently active strombolian vents within the crater that host lava lakes which release the lava by breaching of the cones. In contrast, most vents on MC that feed major effusive events result from secondary vents/ephemeral boccas breaching or tapping from the central magma column somewhere below the level of the summit vents [11].

The next most abundant products observed at MC are pyroclastic cones ( $\sim 340$ cones have been mapped) aligned along a NE-SW trend (Figure 2), corresponding to the CVL alignment (Figure 1). They have the highest spatial density on the upper SW flank of MC (Figure 2). These cones result mostly from the observed moderately explosive activity and range from small spatter mounds to larger spatter-scoria cones. Other observed formations include lahars (volcanic mudflows; Figure 2) graded as a possible ancient hazard around MC [42]. Etindites (nephelinite lavas) are restricted to Mount Etinde (small volcano probably of Miocene age on the lower SW flank of MC; Figure 1; [35,54]). Lastly, are underlying sediments upon which all the above rock types lie (Figure 2; [35]).

\subsection{Evolution of the 1982 Lava Flow Field}

On 16 October 1982, new effusive activity started at MC and continued until 23 November 1982. This eruption occurred after 23 years of quiescence and emplaced a $\sim 7.5$ km-long basaltic 'a'ā lava flow field (Figure 3). A detailed account of the chronology/sequence of this eruption has been given by [47]. Thus, we summarise only elements of the chronology pertinent to the analysis of the lava flow field evolution presented here. Lava, ash, gases and tephra were emitted from a SW-NE trending fissure at an elevation of $\sim 2700 \mathrm{~m}$ above sea level (a.s.l.) on the SW 


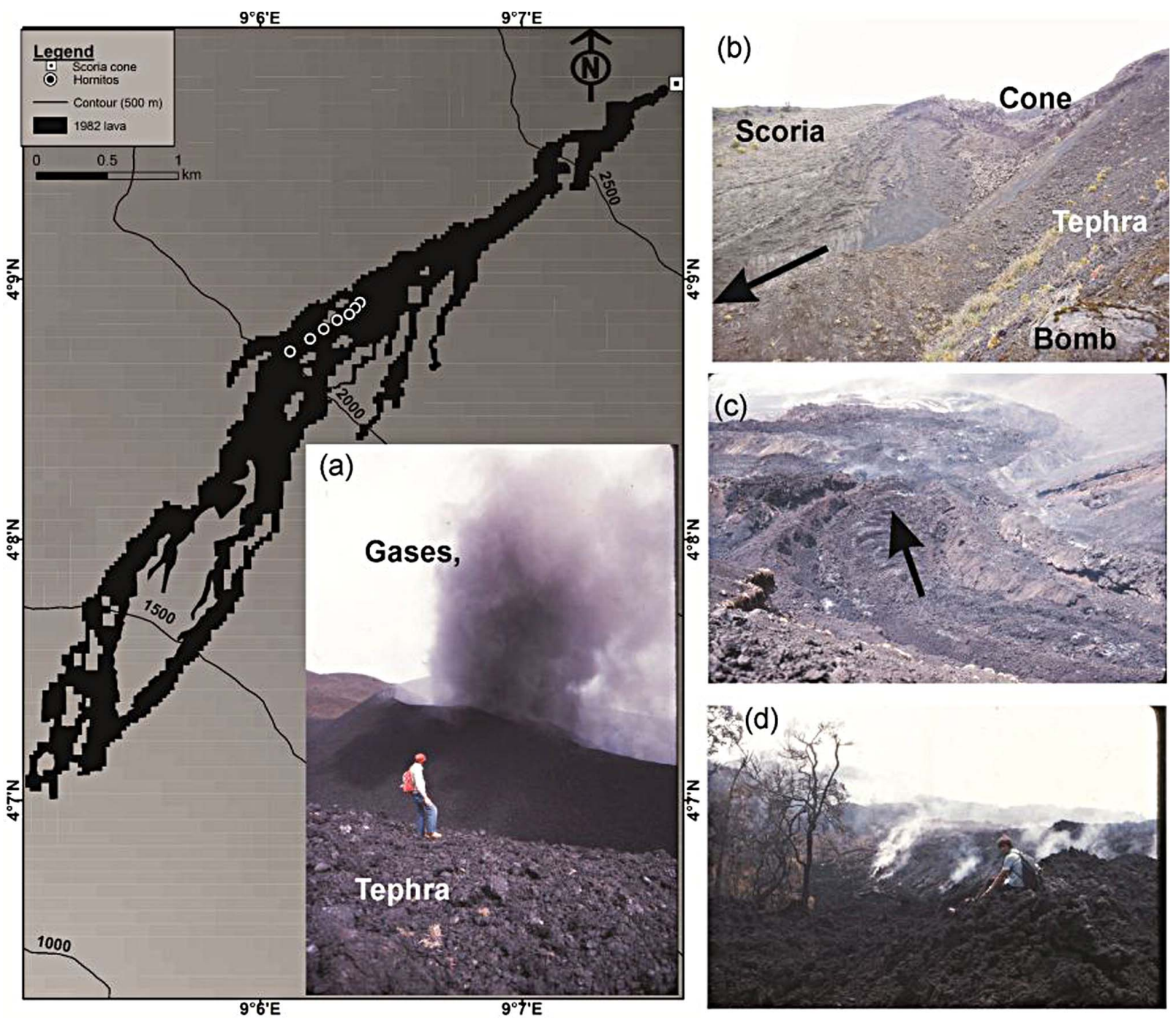

Figure 3. (Colour online) 1982 lava flow field showing the location of the main scoria cone (represented by a square) and the 7 secondary vents (indicated by circles) that contributed to the flow width, thickness and lava volume emplaced for this eruption. (a) Photograph of active cone taken two days (7/11/1982) before the end of the eruption by G. J. Fitton; (b) emplaced scoria cone taken 28 years after (c) firsthand view of the lava channel captured by G. J. Fitton, 24 days after the onset of the eruption (9/11/1982); and (d) landslide debris as observed on the 9/11/1982 by G. J. Fitton.

flank of MC. The observed fissure extended over a distance of $\sim 1 \mathrm{~km}$ down slope.

Moderately explosive activity at the upper end of the fissure led to the formation of a $25 \mathrm{~m}$ high scoria cone by November 7 (Figures 3(a) and (b)). A lava channel with an initial width of $3 \mathrm{~m}$ was observed in the first few days of eruption (Figure 3(c)). Lava flowed in this channel at a velocity of $5.2 \mathrm{~m} \cdot \mathrm{s}^{-1}$ and initial magma discharge rate of $10-30 \mathrm{~m}^{3} \cdot \mathrm{s}^{-1}$ which dropped to $\sim 0.1 \mathrm{~m}^{3} \cdot \mathrm{s}^{-1}$ in the last 24 hours of eruption. Approximately $900 \mathrm{~m}$ down slope from the cone ( 8 November), measurements of an active lava lobe showed that it was $3.5 \mathrm{~m}$ wide, $1.25 \mathrm{~m}$ thick and advanced with a mean velocity of $0.2 \mathrm{~m} \cdot \mathrm{s}^{-1}$ on a slope of $18^{\circ}$. Temperature readings at this point in the flow using a thermocouple produced values of $1045^{\circ} \mathrm{C} \pm$ $5^{\circ} \mathrm{C}-1070^{\circ} \mathrm{C} \pm 5^{\circ} \mathrm{C}$. This led to estimation of initial eruption temperature at $1160^{\circ} \mathrm{C}$ and to average cooling rates of $0.1^{\circ} \mathrm{C}-0.3^{\circ} \mathrm{C} \cdot \mathrm{s}^{-1}$. This lava lobe entered dense forest at $2400 \mathrm{~m}$ a.s.1., $1.5 \mathrm{~km}$ from the cone. Flow front measurements from the main flow lobe (Figure 3) at $1000 \mathrm{~m}$ a.s.l. gave values of $\sim 200 \mathrm{~m}$ wide and $20 \mathrm{~m}$ high.

Between 30 October and 4 November, a landslide occurred just below the main cone (Figure 3(d)) that initiated a debris flow composed of a mixture of older volcanic material and the only just emplaced 1982 lava flow. This debris flow modified the upper part of the 1982 lava (Figure 3(d)) acting as a blockage zone and stopped 1.5 $\mathrm{km}$ from the vent. It produced an elongated depression with a length, width and depth of $500 \mathrm{~m}, 200 \mathrm{~m}$ and 150 $m$ respectively. [47] estimated the total lava volume ex- 
truded at $\sim 10^{7} \mathrm{~m}^{3}$. Other estimated parameters for this eruption include maximum pre-eruptive water content for the magma at $0.6 \mathrm{wt} \%$, viscosity $\left(10^{4} \mathrm{~Pa} \cdot \mathrm{s}\right)$, yield strength $\left(10^{4} \mathrm{~Pa}\right)$ as well as petrographic and geochemical data.

The emplacement of this lava flow field on moderately inclined slopes $\left(12^{\circ}-19^{\circ}\right)$ resulted in distinctive flow field morphologies. The development of a compound lava flow field characterised by several lobes (Figure 3), present an excellent opportunity to examine the morphology and evolution of an intermediate/long-lived 'a'à lava flow field emplaced on inclined surfaces. Unfortunately, during the 1982 eruption, virtually no information (e.g. GPS and ground control points for observed features), was collected from which the flow field morphology and evolution could be examined. Here, fieldwork was carried out to map out observed features and structures on this flow field and describe the surface characteristics of the flow. This data was then used to present details of the morphology and evolution of the flow field, and relate this evolution to quantitative parameters such as slope, effusion rate, number of active vents, flow length, lava tubes and number of active flow lobes. In doing this, we define the characteristics of the 1982 basaltic lava flow field inferred from its emplacement dynamics. From field observations and the narrative given by [47], the lava flow was extremely unstable and suffered from almost constant flow front collapses to feed other flows extending down-slope from stalled flow fronts.

\section{Materials and Methods}

Field observations and measurements (channel width, depth and levee angle) were made at the proximal, medial and dispersed flow portions of the flow field. Details of the surface morphology for the different lava types and structures observed in this flow field were obtained across transversal profiles made within the stable and transitional flow zones. 13 profiles (Figure 4) were measured using a $30 \mathrm{~m}$ tape, an abney level and a compass clinometer. They enabled to describe the physical characteristics of the 1982 lava flow field. Four representative profiles are illustrated here to show changes in channel morphology down-flow (Figures 4(a)-(d)).

Morphology of the flow field at a distance (length) above $5.5 \mathrm{~km}$ (that comprised the dispersed and flow front zones) could not be observed because this portion of the flow is buried by the lower 1999 vents and lava (Figures 1 and 2). Several bifurcations, islands and flow lobes are observed. Our focus is on the WSW branch of the flow field (Figure 3).

Lava thickness was derived from trigonometry. These values were substituted in equations from $[55,56]$ and into Jeffrey's equation to estimate yield strength (levees)

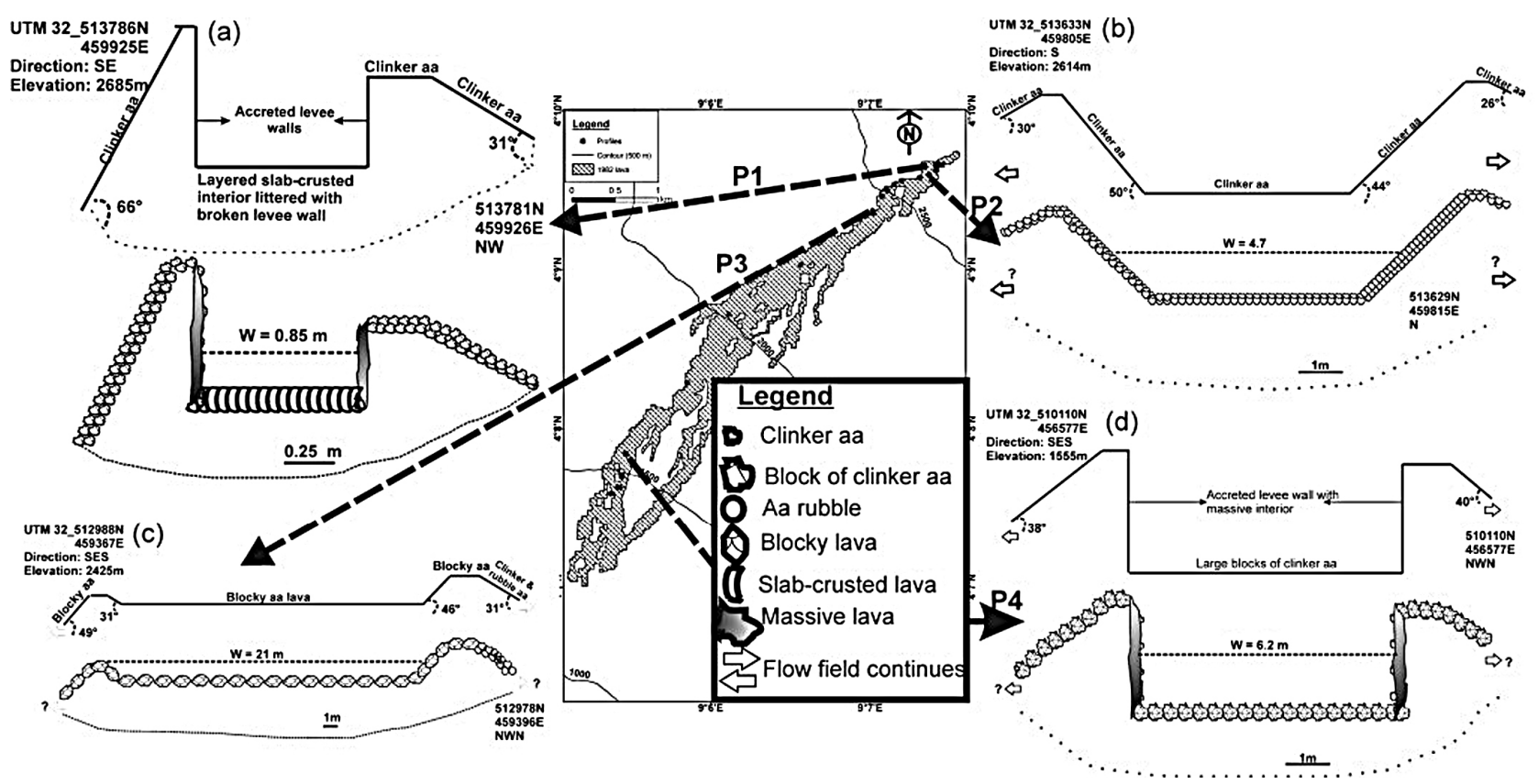

Figure 4. (Colour online) 1982 lava flow map showing profile locations indicated as points that represent the start and end GPS positions of some of the profiles. The illustrated profiles (P1-P4) were made (a) $1 \mathrm{~m}$ from the vent immediately after the observed zone of blockage in Figure 5(a); (b) $200 \mathrm{~m}$ from the vent showing a characteristic trend of clinker 'a'ā morphology that covers the entire section; (c) $1 \mathrm{~km}$ from the vent, dominated by blocky 'a'à lava morphology and (d) $5 \mathrm{~km}$ from the vent showing a dominant clinker 'a'ā morphology (larger blocks) with accreted channel margins. P1 represent the entire flow field width, while P2-P4 represents just the stable channel width. Question marks and arrows are indicative of side channels and the continuation of the flow field. 
and mean channel velocity (Equations (1) and (2)).

$$
\tau=\rho g t \sin \alpha
$$

where $\tau$ is yield strength, $\rho$ is the dense rock equivalent density, $g$ is acceleration due to gravity which is equal to $9.8 \mathrm{~m} \cdot \mathrm{s}^{-2}, t$ is levee thickness and $\alpha$ is the gradient of slope (slope here represents pre-eruptive down flow slope).

$$
V=t^{2} \rho g \sin (\alpha) / B \eta
$$

where $V$ is mean velocity, $\alpha$ is the pre-eruptive down flow slope (obtained from the field and the $30 \mathrm{~m}$ Digital Elevation Model (DEM) for MC) and B is the shape constant considered to be equal to 3 (value is representative of wide channels).

From the estimated velocity $(V)$, channel depth $(d)$ and width $(W)$, effusion rate for lava flowing in these channels was derived (see [57]). A uniform density of 2700 $\mathrm{kg} \cdot \mathrm{m}^{-3}$ was assumed in estimating the above rheological parameters. This is an average density for this lava flow estimated based on previously published whole-rock geochemical compositional data from $[25,39,47])$ following [58] approach. Lava volume for this eruption was reestimated by the planimetric approach proposed by [59]. This involves the measurement of the area covered by the lava flow field (obtained from GIS estimate) multiplied by an estimated mean lava thickness for the flow field.

For the purpose of reconstructing the stable channel geometry, profiles were made at intervals of 100/200 m (for the first one kilometre) and at $1 \mathrm{~km}$ interval from then onwards (Table 1) starting with a profile within a few metres from the vent (Figure 4(a)). Other observations from this flow were obtained between profiles.

\section{Results}

\subsection{Lava Flow Field Morphology}

The 1982 compound 'a'ā lava flow field (Figures 4(a)-(d)) has 6 main and uncountable subsidiary lava flow lobes which branch out in several directions, with some of them meeting up again towards the flow front (Figure 3). The principal flow morphology observed from near-vent to $5.5 \mathrm{~km}$ distance for this lava flow field is clinker 'a'ā lava followed closely by blocky 'a'ā lava. Upper flow proximal lava in the first $17 \mathrm{~m}$ from the vent is slabcrusted lava within the stable channel according to the terminology given by [60]. Most morphological features indicative of lava flow emplacement mechanism and late stage deformation were recorded.

\subsubsection{Large-Scale Flow Field Development and Structures}

1) Scoria Cone

The development of the main cone thought to have fed the greatest volume of the lava flow field was partially documented by [47]. This cone is visible both on Landsat TM, ETM + scenes, and in the field (Figure 5(a)) emplaced on slopes of $16^{\circ}-18^{\circ}$ and breached in the downflow direction. Measurements (GIS) made from the already emplaced $25 \mathrm{~m}$ high cone gave $\sim 350 \mathrm{~m}$ base diameter and $\sim 85 \mathrm{~m}$ crater diameter, occupying an area of $\sim 1.2 \times 10^{5} \mathrm{~m}^{2}$ and volume of $\sim 2.5 \times 10^{6} \mathrm{~m}^{3}(\sim 20 \mathrm{~m}$ thick $)$ respectively. Lava-fountaining up to $300-400 \mathrm{~m}$ high from this cone ([47]; Figure 3(a)) in its explosive phase, led to emplacement of a tephra layer observed for a distance of up to $\sim 200 \mathrm{~m}$ away in the NE direction (along the route used to get to the vent). This layer was sparsely dotted by large bombs $(\sim 1 \mathrm{~m})$ made up mostly of lapilli and sand-sized particles close to vent that became finer away from it (Figure 5(a)). The scoria and lapilli range in size from 2 to $65 \mathrm{~mm}$ in diameter.

The blockage (Figure 5(a)) observed immediately after the cone breached zone was produced $\sim 14$ days after eruption onset [47]. It resulted from a landslide below the cone that produced a debris flow of old volcanic material (ash and scoria) mixed with disrupted remains of the 1982 lava [47]. This blockage came after the establishment of the stable channel (Figure 5(a)) observed immediately after this zone [47]. The observed blockage at the time of eruption prevented the debris flow from taking the direction of the channel. The debris flow deposit was still preserved in the field at the time of the study in the upper sector of the flow field (Figure 5(a)). This debris flow ended with a sharply defined lobate front as described by [47]. It obstructed the flow of lava in the established channel (Figure 5(a)) causing diversion of the flow that led to the production of a secondary channel to the West of the vent which merged a few metres downflow with the primary vent.

2) Secondary Vents

Field investigations revealed a series of 7 late-forming secondary and/or ephemeral (short-lived) vents (Figures 5(b) and (c)). These vents are observed $\sim 2.5 \mathrm{~km}$ away from the main vent (Figures 5(b) and (c)) at $\sim 2180 \mathrm{~m}$ a.s.1, emplaced on slopes of $15^{\circ}-19^{\circ}$, all aligned in the E-W direction within the flow field. These small vent constructs are 3 to $15 \mathrm{~m}$ high (Figure 5(b)), are most often breached in the SE direction (Figure 5(c)), and are spaced at intervals of 2 to $10 \mathrm{~m}$ of each other. Threequarters of them produced lava with clinker 'a'à morphology that flowed in distinct channels within the flow field which disappeared $\sim 20 \mathrm{~m}$ down flow. Most of their walls have already been colonised by mosses. Close inspection revealed that some of these walls are plastered with spatter and clinker (Figures 5(c) and (d)).

3) Levees

Few initial levees were preserved because of variations in flow level and blockages within channels that fa- 
Table 1. Geometrical parameters of the stable channel zone of the 1982 lava flow field.

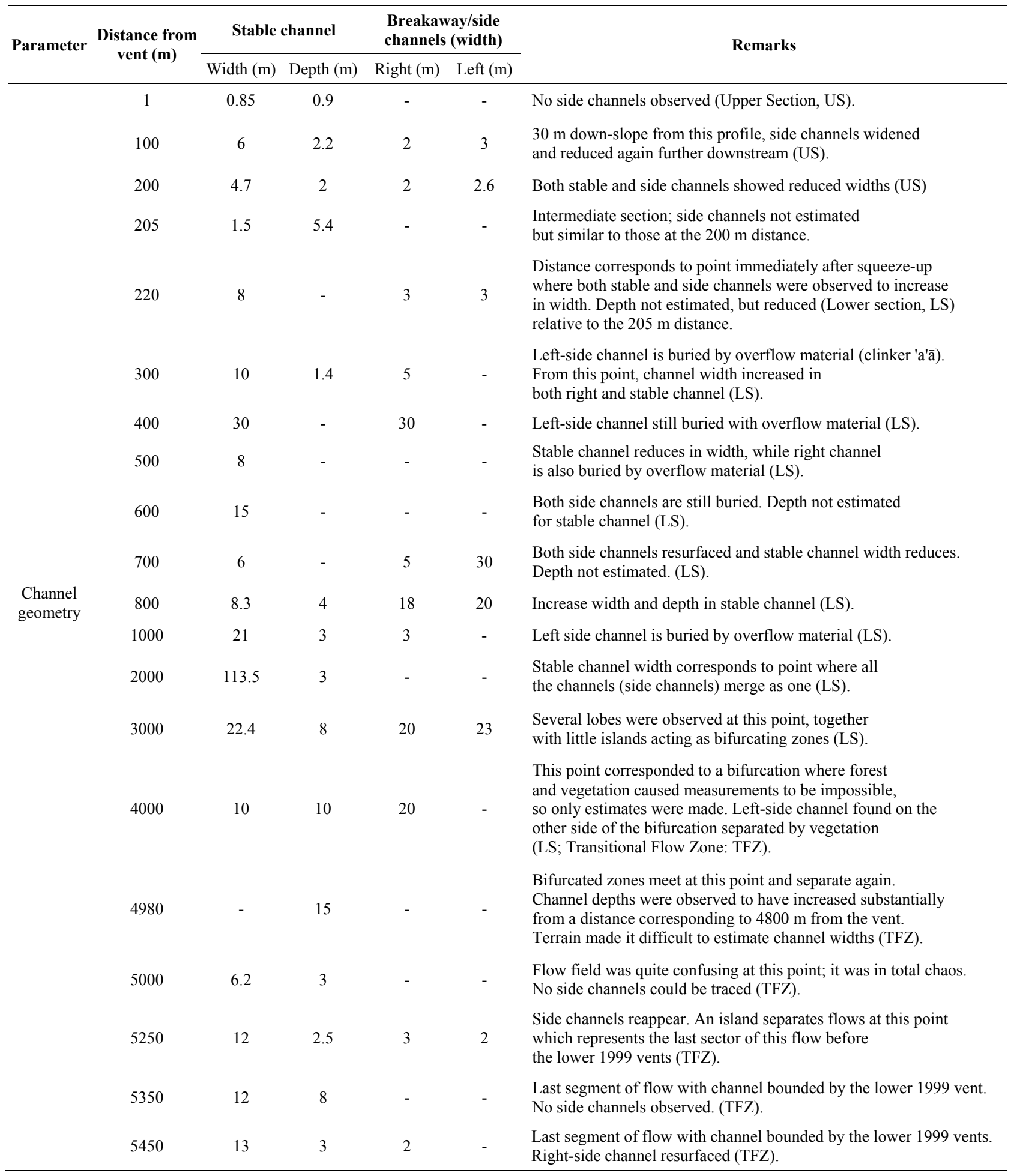

voured over flow events and formation of overflow levees. These events modify levees (Figure 6(a)) and cause flow field widening. Initial levees are characterised by outer slopes of $26^{\circ}$ to $66^{\circ}$. These levees are 0.3 to $2 \mathrm{~m}$ thick (t) with corresponding levee widths of 0.4 to $3 \mathrm{~m}$
(Figures 4(a)-(d), Profiles 1 - 4). Yield strength of initial lava estimated using outer initial levee thickness and angle of rest [55] fluctuates between $10^{3}$ to $10^{4} \mathrm{~Pa}$ across the different profiles. The main lava types that characterised these levees are loose clinker and blocky 'a'à lava 

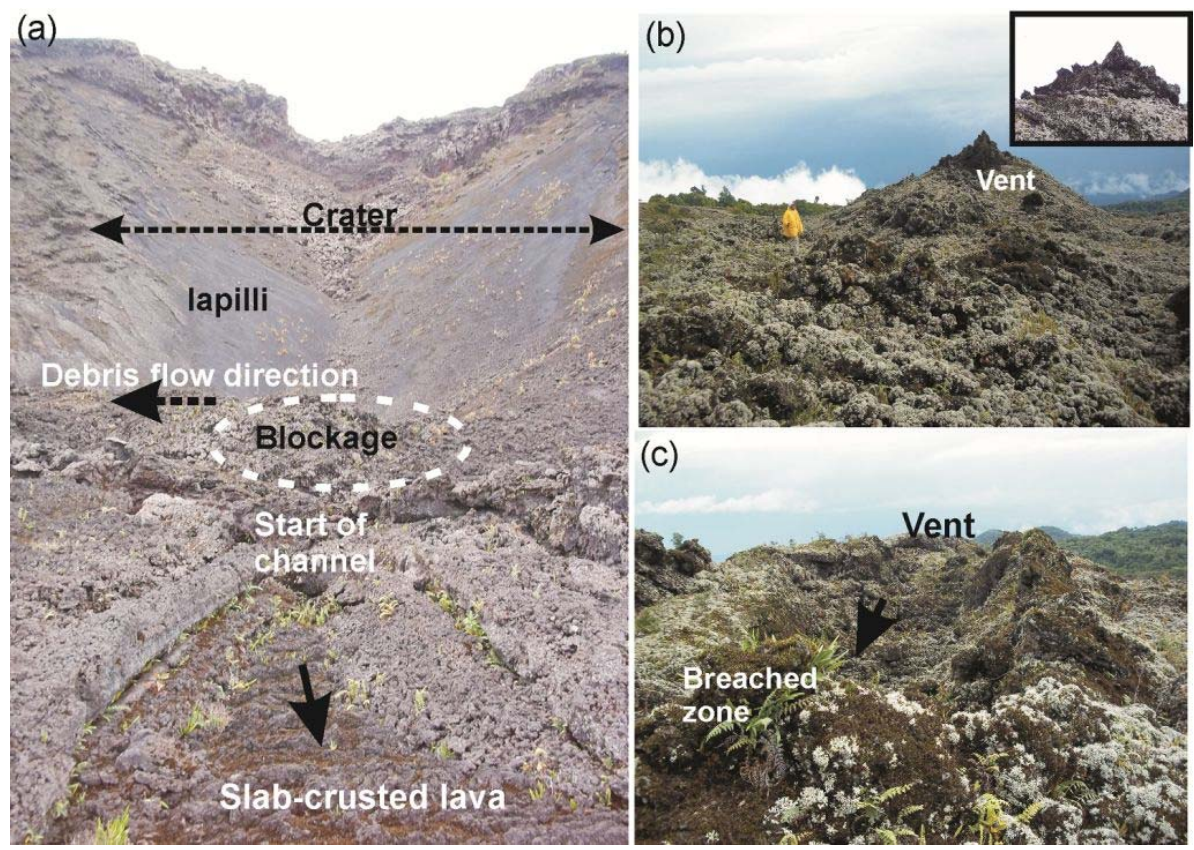

(c)

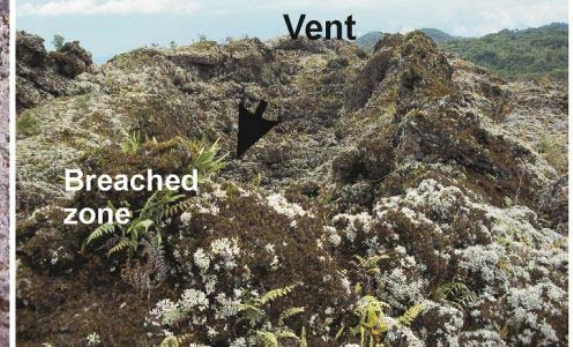

Figure 5. (Colour online) Photographs showing (a) scoria cone with breached zone, tephra, debris flow and the start of channel and (b) and (c). Alignment of secondary vents within channel showing a breached zone.

(Figures 4(a)-(d), Profiles 1 - 4). The inner walls of these levees show horizontal layering and shearing features (Figure 6(b)).

Overflow levees could be distinguished from initial levees because they showed layering of different lava levels believed to represent different flow episodes. Overflow material is basically clinker and blocky 'a'ā lava (Figure 6(a)) and to a limited extent rubble 'a'ā lava (Figure 4(c), profile 3). Typical outer slopes for overflow levees are $30^{\circ}$ to $50^{\circ}$ with levee thickness $(\mathrm{t})$ values of 0.4 to $2.5 \mathrm{~m}$ and levee widths of 0.3 to $2.6 \mathrm{~m}$.

Accretionary levees (Figures 6(b)-(e)) are the dominant levee type. Accreted/agglutinated lava surfaces were observed both on the outer and inner walls of channels. They are characterised by brecciated surfaces (Figure 6(c)) showing shearing features, tension fractures and cooling cracks (Figure 6(d)). They are 0.5 to $8 \mathrm{~m}$ thick. Virtually all of the internal accretionary levees observed are characterised by sub-vertical to vertical inner levee walls (Figures 4(a)-(d), Profiles 1 - 4) with a massive interior texture (Figure 6(e)). Yield strength estimated for this levee type is stable at $10^{4} \mathrm{~Pa}$. Since the flow front could not be observed at the time of this study, no flow front measurements were made. However, [47] gave a width of $\sim 200 \mathrm{~m}$ with a thickness of $20 \mathrm{~m}$ for the main flow lobe.

4) Lava Channels

In this flow field, as for other 'a'a dominated lava flow fields at MC (e.g. 1959, 1999) channels were the dominant preserved transport pathway. Lava in proximal channels (first $100 \mathrm{~m}$ ) flowed with initial estimated velocity and effusion rate of $4 \mathrm{~m} \cdot \mathrm{s}^{-1}$ and $3.3 \mathrm{~m} \cdot \mathrm{s}^{3}$ respectively. Channels are $0.85-5 \mathrm{~m}$ wide, dominated by slab-crusted lava with clinker 'a'ā margins (Figure 5(a); Table 1) observed up to a distance of $205 \mathrm{~m}$ (Figure 7(a)) away from vent. However, these crusted surfaces are not continuous for the whole length of the $205 \mathrm{~m}$. They broke up into slabs after covering distances of 10 to $17 \mathrm{~m}$ (Figure 7(b)). These distances correspond to an increase in slope from $16^{\circ}$ (at-vent) to $18^{\circ}(300 \mathrm{~m})$. These broken slabs probably acted as temporary blockage zones within these channels (Figure 7(c)) while this flow was active. Broken slab material usually piles up forming heaps up to 13 $\mathrm{m}$ long at some locations (Figure 7(c)).

Within a few metres $(\sim 20 \mathrm{~m})$ from vent, secondary channels were observed at the sides of the primary or main channel (Figure 7(c)). These channels are 2 to $3 \mathrm{~m}$ wide, $100 \mathrm{~m}$ from vent Figure $7(\mathbf{c})$ ), and $30 \mathrm{~m}$ wide $\sim 400 \mathrm{~m}$ from vent (Table 1). Effusion rate increased to $\sim 29 \mathrm{~m}^{3} \cdot \mathrm{s}^{-1}$ (100 m distance) and dropped to $13 \mathrm{~m}^{3} \cdot \mathrm{s}^{-1}$ $200 \mathrm{~m}$ away from vent. This drop in effusion rate led to the production of channels ( $200 \mathrm{~m}$ from vent) characterised by a reduced width $(1.5 \mathrm{~m})$ and an increased depth $(5.4 \mathrm{~m})$ with a slab-crusted surface that continued for a distance of $10 \mathrm{~m}$ before breaking up into slabs (Figures 7(a) and (d)). Velocity estimates at these distances had dropped to 2 and $1.4 \mathrm{~m} \cdot \mathrm{s}^{-1}$. Both effusion rate and velocity $\left(12 \mathrm{~m} \cdot \mathrm{s}^{-1}\right)$ increased from these distances up to $1 \mathrm{~km}$ distance. This favoured the formation of wider channels $(6-21 \mathrm{~m})$ and clinker and blocky 'a'ā lava emplaced on slopes of $14^{\circ}-17^{\circ}$. The widest channel (113.5 $\mathrm{m}$ ) in this flow field was observed $\sim 2 \mathrm{~km}$ from vent 

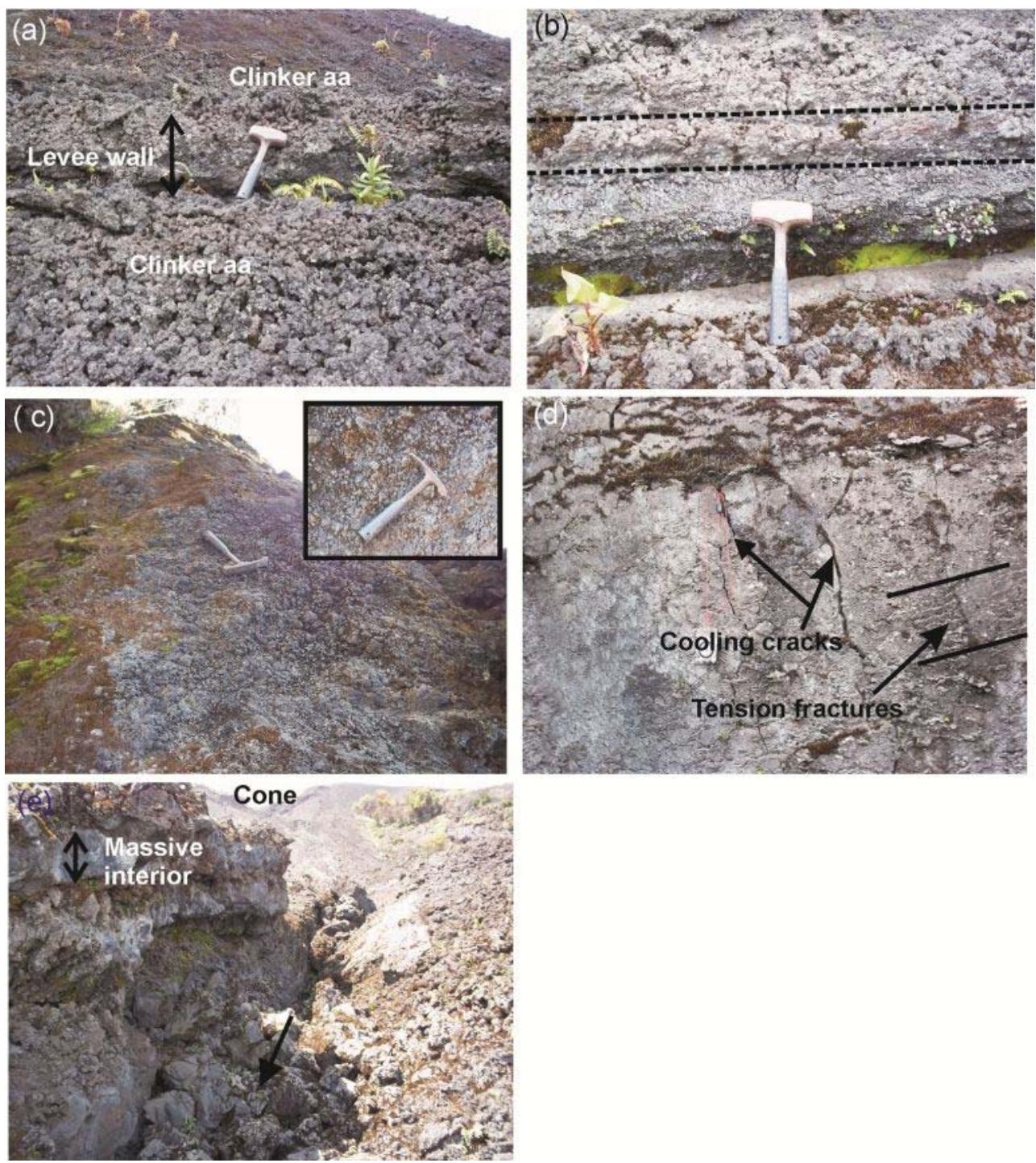

Figure 6. (Colour online) Levees observed at the 1982 lava flow field showing (a) initial/overflow levee over-underlain by clinker 'a'ā; (b) accretionary levee wall showing horizontal layering (broken lines) and fracturing; (c) outer accreted levee wall with highly brecciated surface; (d) levee wall with cooling cracks and tension fractures and (e). massive levee interior with arrow showing lava flow direction within channel.

hosting sealed lava tube surfaces, characterised by reduced velocity $\left(4.5 \mathrm{~m} \cdot \mathrm{s}^{-1}\right)$ and high flow rates $\left(68 \mathrm{~m}^{3} \cdot \mathrm{s}^{-1}\right)$. Channel material is clinker 'a'à emplaced on a slope of $15^{\circ}$.

Lava channels were still considerable wide (10 - $22 \mathrm{~m})$ from this distance but dropped to $6 \mathrm{~m}, 5.5 \mathrm{~km}$ from vent. At this distance, velocity and flow rate had dropped to $0.3 \mathrm{~m} \cdot \mathrm{s}^{-1}$ and $13 \mathrm{~m}^{3} \cdot \mathrm{s}^{-1}$ respectively. The lava type here is clinker and blocky 'a'ā lava emplaced on slopes of $12^{\circ}$ $14^{\circ}$. From the estimates made, an average velocity and flow rate of $4.5 \mathrm{~m} \cdot \mathrm{s}^{-1}$ and $26 \mathrm{~m}^{3} \cdot \mathrm{s}^{-1}$ were produced for this flow. Taking an average lava thickness of $5 \mathrm{~m}( \pm 2 \mathrm{~m}$; field estimates), an area of $2.6 \times 10^{6} \mathrm{~m}^{2}$ (GIS estimate), this eruption produced lava with a volume of $\sim 1.3 \times 10^{7}$ $\mathrm{m}^{3}$.

\section{5) Lava Tubes}

Lava tubes were first observed in channels at a distance $600 \mathrm{~m}$ from vent (Figure 7(b)). They could be distinguished based on their elongated forms, continuous surface morphology, raised margins and extensive lengths relative to that of the surrounding rocks (Figures 7(b) and (c)). These tubes are characterised by a spinose surface with crusts just a few $\mathrm{cm}$ thick (Figure 7(b)). At $600 \mathrm{~m}$ distance, an observed lava tube is $10 \mathrm{~m}$ long and $\sim 2 \mathrm{~m}$ wide (Figure 7(b)). These lava tubes were abundant within the primary channel $(\sim 2 \mathrm{~km}$ from vent) where the channel is widest. From their surface appearance, 5 could be distinguished with extensive lengths $(\sim 10-20 \mathrm{~m})$ that became buried down-slope by channel material. This is $500 \mathrm{~m}$ (up-slope) from the point where 

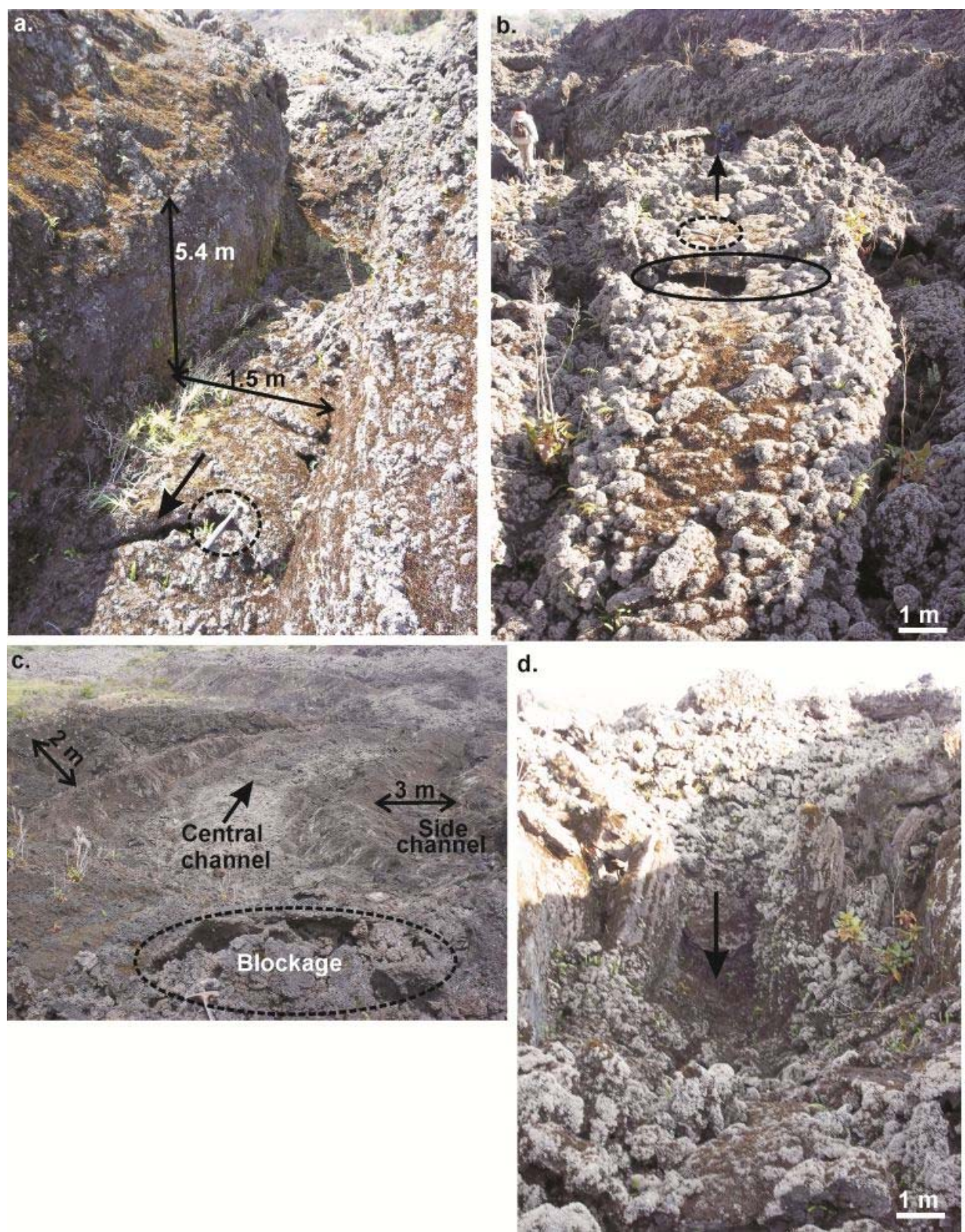

Figure 7. (Colour online) Channel morphology across the 1982 lava flow field showing (a) intermediate stable channel with reduced width and increased depth with slab-crusted floor; (b) lava-tube/slab-crusted surface with a broken surface (encircled); (c) blockage within channel characterised by tilted pahoehoe-slabs hosting side channels on both sides of the stable channel zone bounded by levees and (d) continuation of intermediate stable channel zone observed further down-stream after slabs had broken up in (b) above. Arrows within channels are indicative of flow direction.

secondary vents were observed.

\subsection{Down-Flow Channel Geometry and Small Scale-Structures}

Here, on the basis of channel geometry fluctuation, we split the stable channel zone of the flow into three sections: 1) an upper section characterised by wider than deep channels; 2) an intermediate section governed by deeper than wide channels and 3) a lower section where channels resume their normal trend as in the upper section being wider than deep. This zone is followed by the transitional channel zone observed $\sim 4 \mathrm{~km}$ down-flow.

\subsubsection{Stable Channel Zone}

Table 1 and Figures 8(a) and (b) give details on the stable channel geometry at a distance starting from $1 \mathrm{~m}$ from the vent, progressively down-stream. The widths of breakaway/side channels are also given at the corresponding 

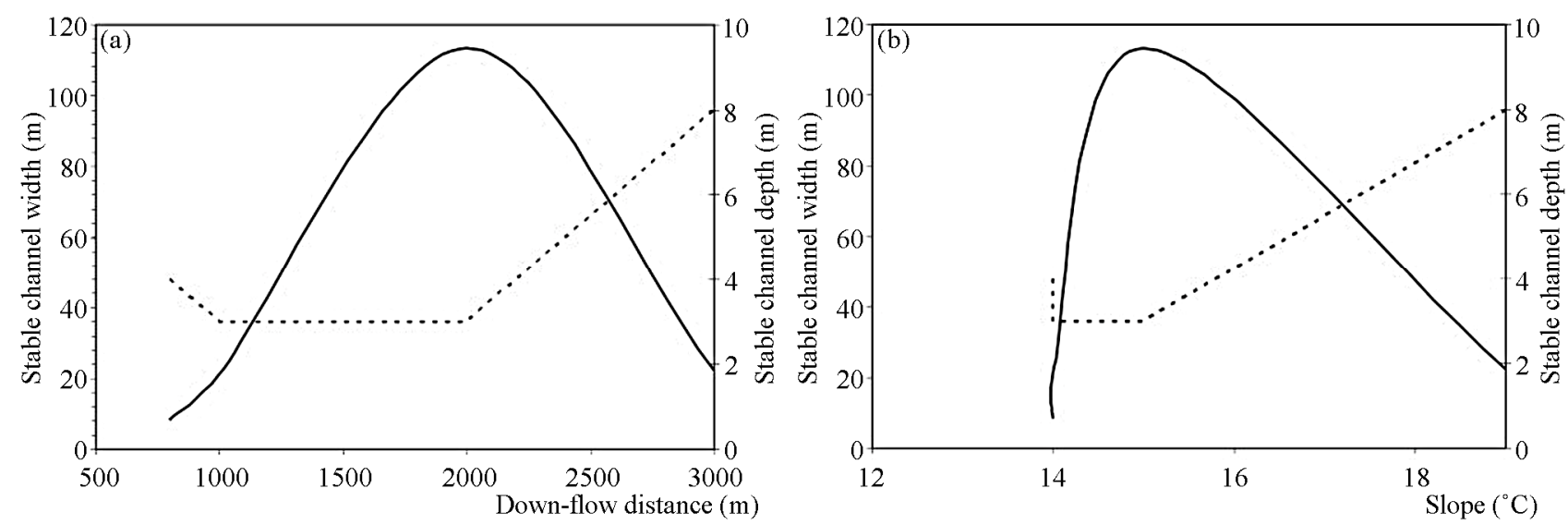

Figure 8. Plots of stable channel geometry showing (a) down-flow distance and (b) slope against stable channel widths and depths.

distances (Table 1). Depth was estimated from internal levee height.

\section{1) Upper Section}

This zone represent channels observed at distances of 1 to $200 \mathrm{~m}$ from vent characterised by widths of $0.85 \mathrm{~m}$ to $4.7 \mathrm{~m}$ and depths of 0.95 to $2 \mathrm{~m}$ (Figures 4(a) and (b); Table 1). Side channels observed in this section (Figure 7(c); Table 1) merged down-flow with the main channel at some locations. Other subsidiary channels formed further down-flow with larger widths (5 to $30 \mathrm{~m}$ ).

2) Intermediate Section

This section is characterised by reduced channel widths and increased depths (Figures 7(a) and (d); Table 1) and covers the smallest portion of the stable channel zone $(\sim 25 \mathrm{~m})$.

3) Lower Section

In the lower section of the stable channel zone, channel widths increased from 24 to $113.5 \mathrm{~m}$ (Table 1). This took place at distances 1 and $2 \mathrm{~km}$ away from vent respectively in the SW branch of the flow. Channel depths at the above distances remained fairly stable at $3 \mathrm{~m}$. It increased to $8 \mathrm{~m}, 3 \mathrm{~km}$ from vent (Figures 8(a) and (b); Table 1).

\subsubsection{Transitional Zone}

On this flow field, this zone was observed immediately after the stable channel zone and covers the distance beyond $\sim 4 \mathrm{~km}$ from vent. In this zone, channels were most often deeper $(3-15 \mathrm{~m})$ than wide $(6-13 \mathrm{~m})$ characterised by a surface mixture of clinker and blocky 'a'ā lava. The slopes here are also less steep $\left(12^{\circ}-14^{\circ}\right)$ with reduced flow velocity $\left(0.3-3.6 \mathrm{~m} \cdot \mathrm{s}^{-1}\right)$. At the 5 to $5.5 \mathrm{~km}$ distance, the flow field became quite chaotic. However, channels could still be observed, so it could not be classified as a dispersed flow zone. Blocky 'a'ā lava dominated at these distances before the 1982 flow field reached the lower eruptive vents and lava flow field of the 1999 eruption.

\subsubsection{Small-Scale Structures: Squeeze-Up and Tumulus}

Numerous pinnacles which represent rafts, slabs or transported lava blocks left behind by the flowing lava were observed on the flow field (Figure 9(a)). They acted as blockages within the channels. Pressure ridges and squeeze-ups are the only prominent compressive features that have so far been observed at the 1982 lava flow field. Four pressure ridges were observed at $\sim 160 \mathrm{~m}\left(17^{\circ}-18^{\circ}\right)$ from vent within this flow field. These ridges were exposed as clinkery linear hummocks found perpendicular to the direction of flow with heights of $<1 \mathrm{~m}$. They were observed within the upper section of the stable channel spaced at intervals of 0.1 to $0.2 \mathrm{~m}$ from each other. They can be attributed to the estimated minor drop in effusion rate from 29 to $13 \mathrm{~m}^{3} \cdot \mathrm{s}^{-1}$.

1) Squeeze-Ups

A squeeze-up (Figures 9(b) and (c)) was encountered $\sim 15 \mathrm{~m}$ down slope from the intermediate stable channel section ( $\sim 220 \mathrm{~m}$ from the vent). It is characterised by an irregular spinose surface showing grooves and chatter marks at the sides, with toothpaste or a peeling lava texture on the surface (Figure 9(b)). It terminates with sharply titled slabs at the topmost part (Figures 9(b) and (c)). Channel material was made up of clinker 'a'ā and broken slabs from the intermediate stable channel zone (Figure 9(c)). Field observations indicated that this squeeze-up marked the end of the intermediate stable channel section. Channel widths increased from this point $(8 \mathrm{~m})$ onwards marking the beginning of the lower section of the stable channel zone.

2) Tumulus

A characteristic inflation feature that has been widely observed on other basaltic lava flow fields but never described in previous literature for MC lava flow fields are tumuli. Located $500 \mathrm{~m}$ from the vent, a tumulus (Figures 9(d)-(g)) was observed within the stable channel zone (lower section) being texturally different from its sur- 


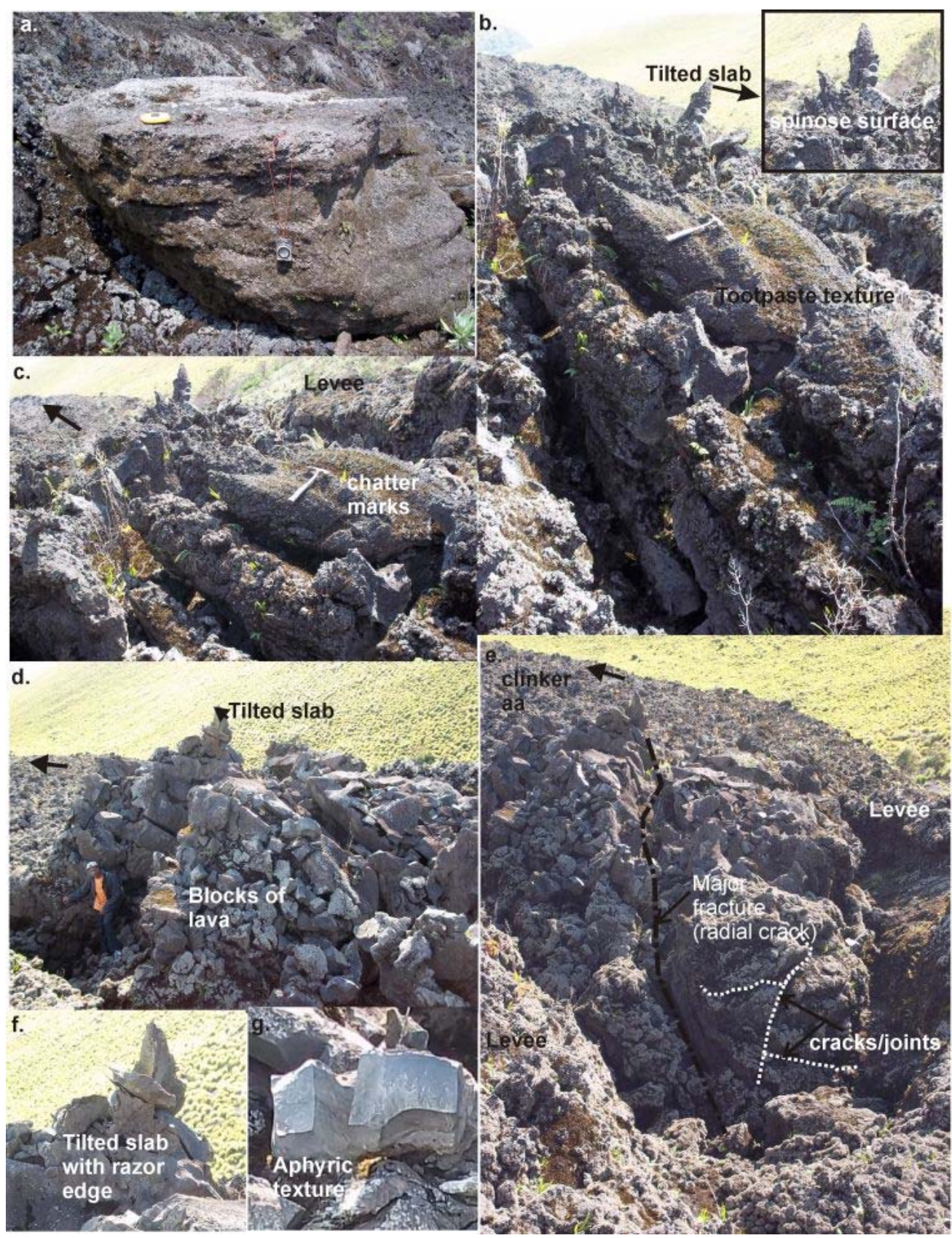

Figure 9. (Colour online) Other structural features observed within channels at the 1982 lava flow field showing (a) large abandoned block of lava; (b) and (c) side-views of squeeze-up characterised by a spinose surface with chatter marks; (d) side-view of tumulus with tilted, rectangular, angular and polygonal blocks of lava; (e) front view of tumulus showing main fracture zone (radial crack) with cracks and joints surrounded by clinker 'a'à; and (f) and (g). Close-up of tumulus slab and blocks. Arrows indicate flow direction.

rounding material. It corresponds to a slope of $17^{\circ}$ and high yield strength $\left(10^{4} \mathrm{~Pa}\right)$. It is characterised by an irregular surface, numerous fractures, joints and cracks, broken blocks, a massive base with tilted and polygonal slabs at the top (Figures 9(d)-(f)). It also has a prominent axial cleft ( $\sim 5 \mathrm{~m}$ long, 0.5 - $2 \mathrm{~m}$ wide, $0.3-0.5 \mathrm{~m}$ deep) and smaller subsidiary clefts aligned sub-parallel to the main axial cleft (Figure 9(e)). The observed fractures and joints are oriented N-W, E-W and N-S (Figure 9(e)) following the direction of the cone. The interior of the lava blocks showed a highly aphyric texture (Figure 9(g)). This tumulus is $\sim 4.5 \mathrm{~m}$ high and has an elongated ridge-like shape in plan form. Its surrounding channel material is basically clinker 'a'ā characterised by accreted levee walls (Figure 9(e)). Lava type observed immediately after this feature is clinker 'a'à. 


\section{Discussion}

\subsection{Significance of the Observed Structures at the 1982 Lava Flow Field}

The $16^{\text {th }}$ of October to mid November 1982 eruption was initiated as a fissure eruption that rapidly became concentrated on a single vent [47]. It produced a compound basaltic 'a'ā lava flow field characterised by several lobes and islands at just one site. This lava flow field is an excellent example of a compound channel-fed 'a'ā dominated flow where both clinker and blocky 'a'ā lava occupied distinct portions of the final lava flow when compared to other 'a'à-dominated lava flow fields at MC. The scoria cone observed at $\sim 2700 \mathrm{~m}$ a.s.l., following eruption account from [47] and from field observations, contributed to the cooling-limited length of this flow. From previous eruptions like the 1999 eruption [25] and from field observations (even though not well constrained), MC lavas take between 3 - 6 days to attain $80 \%$ - $90 \%$ of their cooling-limited and final flow lengths. The observed secondary vents (found inclusive in this lava flow field) and lava tubes emplaced in the later stage of the eruption possibly contributed to flow thickening and widening than lengthening. The formation of the $1982 \mathrm{sec}-$ ondary vents may be linked to an increase in effusion rate caused by a pulse in supply to the main vent which may result in the opening of new vents to cope with the increased flux as observed on an active lava flow field at Mount Etna [45]. An alternative approach could be that they resulted from backflow pressure from a stagnated flow front due to rheological maturation [61].

The difference between the 1982 secondary vents with the ephemeral boccas described by [6] at Etna, is that they are not simply openings but are characterised with considerable heights $(3-15 \mathrm{~m})$. They were also observed in the medial section of the flow and not close to the flow front as common on other basaltic lava flow fields [6, $26,60]$. The similarity between these vents and the ephemeral boccas of $[6,26]$ is that their emplacement maybe linked to the presence of lava tubes observed within this flow field. Blockages observed within channels and effusion rate fluctuations possibly resulted in breaching events [6] that produced the numerous flow lobes and branches observed on this flow field (Figure 3).

Tubes as used here and on other lava flow fields means a subsurface lava pathway that could drain to leave a self-supporting roof $[6,26,62]$. Lava tube surface morphology at the 1982 lava flow field is similar to those observed at lava flow fields of the Faroe Islands [1]. The presence of these lava tubes possibly suggests initial sealing and embryonic tube development $[26,63,64]$.

Following the terminology of [65], three levee types were observed at the 1982 lava flow field: initial, accretionary and overflow levees. Initial levees here refer to static marginal levees that define a channel [13]. Accretionary and overflow levees represented the dominant levee types observed on this flow field. Both levee types were absent at the 1959 compound 'a'ā flow field at MC [2]. Accretionary levees made up $\geq 50 \%$ of levees on this flow field. These levees contrasted with those described by [13] in an open channel at Mount Etna as the latter were characterised by over-hanging channel walls. Their formation and high percentage at the 1982 lava flow field can be linked to a steady slow rise of lava level [65] or from back-pressure from a stagnating flow front which favours lava thickening $[15,61]$. This led to the smearing of ductile lava at the margins of the channel-contained stream onto the levee tops and walls [15] which welded to form solid levees with textures that showed elongation of welded clasts in the down-flow direction [66]. Tension fractures observed on the walls of accretionary levees at the 1982 lava flow field are attributed to the movement of adjacent lava [11].

In this study, overflows describe transient events that are restricted to the surrounding of the levees [17]. Overflow levees were marked by different layers of clinker and blocky 'a'à lava morphologically different from those observed at other lava flow fields at MC. Overflow levees at the 1999 and 2000 lava flow fields at MC were made up of different layers of clinker 'a'à and overflow pahoehoe drapes $[8,11]$. Overflow levees possibly portray a situation of fluctuation and artificial sudden shortterm back pressures and increases in effusion rates probably caused by the disruption of blockages within these channels $[6,13,17]$. Channel levee overflows, breaching and development of different flow lobes at the 1982 lava flow field, favoured flow field widening and possibly promoted lava tube formation [17]. The observed overflow levees at the 1982 flow field capped the initial levees similar to what $[8,13]$ observed at Mount Etna and for the 1999 lava flow field at MC respectively. Rubble levees that occupy distinct portions close to the flow front of historical MC lavas $[2,8,11]$ were practically absent. This can be attributed to the fact that the last $\sim 2 \mathrm{~km}$ to the flow front are now buried underneath the lower 1999 vent constructs and flow field. Rubble levees that had possibly formed within channels had been modified by repeated episodes of flow to form overflow levees as observed at an active lava flow field at Etna [13].

The change in open channel lava flow morphology for this eruption could be attributed to change in slope and fluctuation in effusion rates as described in Section 4.1.1 (Figures 8(a) and (b)). Moderately inclined slopes $\left(12^{\circ}\right.$ $16^{\circ}$ ) and low flow rates favoured the formation of wider than deep channels together with slab-crusted and blocky 'a'ā surface morphology. Whereas steep slopes and higher flow rates favoured the formation of deeper than wide channels and clinker 'a'à. The relationship between steep 
slopes and clinker 'a'à formation is a common feature on lava flow fields at Mount Etna [31].

The 1982 lava flow field displays a similar systematic, spatial variation in structure and morphology as those described by [44] at Mauna Loa, Hawaii. Following [44] classification, two different zones could be identified on this flow field: stable channel zone (upper, intermediate and lower sections) and the transitional flow zone. The division of the stable channel zone into three sections is due to their gross fluctuation in channel geometry. This zone that comprised three sections covered a distance of $\sim 4 \mathrm{~km}$. A similar sub-division (upper and lower sections) for this zone was made by [14] for an active lava flow field at Santiaguito Volcano, Guatemala. Similar to the stable channel zone of [13], the 1982 stable channel zone was characterised by fluctuating channel widths and depths.

The transitional channel zone is identified on other basaltic lava flow fields by a marked change in lava morphology, increased channel widths and sheared flow margins $[13,16,44]$. Increased channel depths $(8-15 \mathrm{~m})$ and a greater percentage of blocky 'a'ā lava over clinker 'a'ā marked this zone at the 1982 flow field. [13] attributed the down-flow transition from one zone to the other as a reflection of decreasing channel maturity. Clinker and blocky 'a'à lava were the principal channel material. The growth of clinker and blocky 'a'ā lava at basaltic flow fields has been extensively discussed by [27,30, $67,68]$. These lavas maintain a significantly disrupted crust. Their flow advance is governed by internal lava close to the front (flow lobe) moving with a uniform steady long-term motion. Flow widening and possibly lengthening is limited by the lava crust $[30,68]$.

The occurrence of the observed squeeze-up and tumulus within the central part of the channel believed to be an area where the crust is most coherent [6], suggests that pre-existing crustal weaknesses may play a role in determining the locations of these features. The squeeze-up probably formed when the flow encountered an obstacle and the pressure within it caused uplift of the crust [69] and/or from moderate flow rates. It then acted as a blockage zone for subsequent flows. The "toothpaste" [3], [4] and/or "peeling" texture [6] that characterise the surface of the squeeze-up is indicative of brittle deformation of the outer layer. The formation of the tumulus could be attributed to a late-stage development in the flow field which commonly involve the very slow extrusion of high yield strength lava [6].

Their preservation in these channels and the absence of overflow lava on them, suggest that they were emplaced in the waning stages of this eruption. Pressure ridges are typical features observed at points of break in slope at other basaltic 'a'à lava flow fields at MC. Their presence within channels in this flow field may be due to insufficient internal pressure from an incoming flow to disrupt the flow front. This slowly led to an increase in internal pressure that caused crustal uplift [33]. These features might have also resulted from the hydrostatic pressure head that builds up within lava tubes [70]. Both pressure ridges and squeeze-ups are compression-induced features, but the internal process that led to their formation is basically inflation (see $[11,46]$ ).

\subsection{The Growth of Tumulus on the 1982 'a'ā Lava Flow Field}

For the first time based on past studies of historical lava flow fields at MC, a tumulus was documented on the 1982 lava flow field even though we have also observed them to occur within channels at the lower 1999 lava flow field at MC. Tumili are products of crustal uplift within lava flow fields $[6,12,29,33,71,72])$. In this study, tumulus could be differentiated from pressure ridges by the fact that it had a well-defined traceable outer margin and a major axial fracture (Figures 9(d) and (e)) which displays a morphology indicative of tumulus-forming process as described by $[12,33,72]$. Early existing literature on tumuli associated them with pahoehoe flow fields on Hawaiian [33], Icelandic volcanoes [71] and in the Deccan Volcanic Province [29]. Recent studies on Etnean 'a'à lava flow fields have cited the presence of tumuli $[6,12,17,45,63,72]$. Based on their morphology, tumuli are classified differently at different volcanoes.

A closer link exists between the focal tumuli of [72] observed at the 1983 'a'ā flow field at Mount Etna with that observed at the 1982 lava flow field at MC. Both of them occurred on 'a'ā-dominated lava flow fields characterised by an arcuate rampart of uplifted angular blocks of massive lava and tilted slabs that forms the topmost part of the tumulus (Figure 9(d)). These blocks of massive lava represent the uplifted and fragmented crust of the earlier 'a'a flow and mark the axis of uplift (Figure 9(d)); [72]). The focal tumuli of [72] served as a site of lava discharge from a number of vents, whereas there was no evidence for lava extrusion after the tumulus formation at the 1982 lava flow field. This suggests that lava continued to flow in tubes underneath the sealed 'a'ā crust. This is supported by the secondary vents observed down-flow from this feature. Another supposition is that this tumulus formed during waning effusion rates or when lava encountered an obstruction, which caused back pressure and inflation of the crust to produce this feature.

The numerous fractures, cracks and joints observed on this tumulus (Figure 9(e)) are cooling structures that may have formed prior to tilting of the original subhorizontal lava surface [71] as a result of brittle deformation [6]. Its height is a function of uplift [72]. The steep 
slope $\left(17^{\circ}\right)$ and the position (hosted within a channel) on which this tumulus was emplaced, suggests that its formation was highly influenced by the state of the surface crust $[6,12]$. Its possibly late-stage emplacement and location favoured cooling and thickening of the crust (within a tube) that required very high overpressure in the flow's interior to deform the crust where it is coherent (within channel), giving rise to localised inflation $[6,12,71]$. The crust is able to accommodate the incoming lava without breaking as long as the tensile strength of the lava crust exceeds the pressure of inflowing lava. The axial and circumferential cracks that later developed then divided the uppermost brittle part of the lava crust into blocks (Figure 9(d); [71]).

Its possibly late-stage development is supported by the fact that steep slopes usually provide more down-slope impulse for flow growth, thereby retarding the vertical growth component of such flows [12]. In the past, tumulus formation has been mostly attributed to shallow-moderate slopes $\left(0^{\circ}-4^{\circ}\right)$ and nearby stagnating flow fronts $[33,71]$. On 'a'ā flow fields tumuli have been found associated with lava tubes and secondary and/or ephemeral vents $[6,12,17,63,72]$.

\subsection{Lava Tubes at the 1982 Lava Flow Field and Their Implication for Flow Widening and Hazard Assessment}

Lava tubes are common features observed at dominantly channel-fed 'a'ā lava flow fields at MC from the proximal right through to the distal end $[2,8,11,25,34]$. They are mostly found hosted within channels distinguished by their extensive lengths, non-measurable depths and traceable outlines. Their occurrence at dominantly channelfed 'a'a lava flow fields is not restricted to MC but is also common at Etna $[5,6,12,13,17,26,63]$. It is a typical feature common in fissure eruptions as described by [63]. So, far, all the documented historical eruptions at $\mathrm{MC}$ are fissure eruptions irrespective of the lava type produced. Lava tubes may play a significant role in flow lengthening on the emplacement of extremely long duration ( $>2$ months) cooling-limited flows [63]. However, this aspect is yet to be fully investigated in models that predict lava flow length for cooling-limited flows (e.g. the FLOWGO model; [18]). We therefore suggest that future lava flow models should take into account the possibility of reactivation and lengthening of long-duration cooling-limited flows by lava tubes. So far, this aspect does not fully apply to cooling-limited lava flow fields at MC since eruption durations rarely exceed 2 months.

At the 1982 lava flow field the formation of the secondary vents, squeeze-ups and tumulus may all be linked to the presence of lava tubes within this flow field. From literature, surface features such as tumuli, collapses, breakouts and secondary vents on 'a'ā lava flow fields all suggest the presence of lava tubes [63]. At the 1982 lava flow field, it is believed that these lava tubes may have developed within the eruptive fissure that initiated this eruption or when channels crusted over. As the eruption duration increased, later flows covered features related to previously formed tubes making them difficult to detect [26]. At the 1982 lava flow field, the presence of these tubes become evident when the tube was obstructed or pressure increases caused breakouts along the roof (Figure 7(b)) or sides of the tubes. Breakouts that took place at changes in slope, remained localised and led to the production of the observed tumulus and squeeze-up (Figures 9(b)-(e); [26]).

Changes in topography permitted the formation of secondary vents from the fronts of these tubes [63]. This process may explain the presence of the 7 secondary vents observed $\sim 2.5 \mathrm{~km}$ from the main vent. This is supported by the presence of some sealed lava tubes within channels $\sim 2 \mathrm{~km}$ from the vent. The opening of these vents drained the upslope portion of the early-formed tube sector. The defined alignment of these secondary vents within the flow field spaced relatively close to each other, suggests that this point was a zone of crustal weakness and that these vents were probably fed by lava flowing underneath the crust.

The opening of these short-lived secondary vents probably enhanced the reactivation of this flow field and resulted in a consequent increase in flow field width and thickness having a negligible effect on flow length. This is because these secondary extrusion points transported lava through channels directly into the flow field from their breached zones. These channels were not extensive ( 10 - $15 \mathrm{~m}$ long) and were found just like the vents enclosed within the lower section of the stable channel zone. From field observation, we rule out the possibility that these vents present a second emission site due to the many evidences explored in this study which suggest that they were secondary vents that came at a later stage of the eruption. We hereby acknowledge just one site for the 1982 eruption.

\section{Conclusion}

In this paper, for the first time, the morphology and channel geometry of the 1982 lava flow field is documented $\sim 30$ years after its emplacement. The new found interest in the morphology and physical characteristics of historical MC lavas $[2,8,11]$ has revealed a variety of lava structures which has resulted in an increased understanding of the nature and dynamics of these lava flow fields relevant in lava flow hazard assessment. From field 
findings, this eruption produced a dominantly channelfed compound 'a'ā lava flow field supplemented by a network of 7 secondary vents and lava tubes similar to other basaltic 'a'ā lava flow fields emplaced at Mount Etna $[5,6,12,13,26]$. Lava morphologies at the 1982 'a'ā flow field exhibited a broad spectrum of surface types ranging from slab-crusted lava, squeeze-up, tumulus, to clinker and blocky 'a'ā emplaced on inclined slopes which are challenging to interpret when already emplaced.

The final large- and small-scale morphology of this flow field depended on many factors including yield strength, flow rate and slope. Levee, tumulus and squeezeup formation are attributed to high lava yield strength. Channel geometry fluctuation down-slope is attributed to changes in slope and flow rate. The observed link between effusion rate and significant morphological changes on this flow field highlights the need to monitor these effects throughout the emplacement of basaltic lava flow fields. Even though challenging, this will help improve the ability to forecast stochastic processes [6]. Flow field widening and thickening was favoured by overflow events and the observed secondary vents and lava tubes. [6] suggested that sites of secondary vents may be used as the starting point for the simulation of new flows to assess their possible consequences. The presence of the observed 7 secondary vents within the 1982 lava flow field, further complicates modelling for this flow field, requiring more sophisticated stochastic models which are yet to be developed. However, for a start this flow could be modelled using numerical models that have been used to model Etnean and Hawaiian cooling-limited lava flows [18] that exhibit a similar morphology as MC lava flows.

All the other features (squeeze-ups, pressure ridges, pinnacles) observed on this flow field have been documented on other historical MC lava flow fields with the exception of tumulus. The observed features are interpreted to be driven by rheological changes that occur as lava advanced downflow. The presence of lava tubes on this 'a'a-dominated lava flow field emphasises the findings by $[26,63]$ that lava tubes can also occur on 'a'à-dominated lava flow fields previously thought to be typical of pahoehoe flow fields [73].

\section{Acknowledgements}

This work is part of a Ph.D. research of Mabel N. Wantim, financed by the "Vlaamse Interuniversitaire RaadUniversitaire Ontwikkelingssamenwerking" (VLIR-UOS; Flemish Interuniversity Council-University Development Cooperation) under the joint partnership of Ghent University in Belgium and the University of Buea in Cameroon. Special thanks go to Godfrey J. Fitton at the University of Edinburgh for providing photographs of the active 1982 eruption and to the anonymous reviewers.

\section{REFERENCES}

[1] S. R. Passey and B. R. Bell, "Morphologies and Emplacement Mechanisms of the Lava Flows of the Faroe Islands Basalt Group, Faroe Islands, NE Atlantic Ocean," Bulletin of Volcanology, Vol. 70, No. 2, 2007, pp. 139156. doi:10.1007/s00445-007-0125-6

[2] M. S. Njome, C. E. Suh, R. J. Sparks, S. N. Ayonghe and J. G. Fitton, "The Mount Cameroon 1959 Compound Lava Flow Field: Morphology, Petrology and Geochemistry," Swiss Journal of Geosciences, Vol. 101, No. 1, 2008, pp. 85-98. doi:10.1007/s00015-007-1245-x

[3] H. C. Sheth, J. S. Ray, R. Bhutani, A. Kumar and R. S. Smitha, "Volcanology and Eruptive Styles of Barren Island: An Active Mafic Stratovolcano in the Andaman Sea, NE Indian Ocean," Bulletin of Volcanology, Vol. 71, No. 9, 2009, pp. 1021-1039. doi:10.1007/s00445-009-0280-Z

[4] H. C. Sheth, J. S. Ray, A. Kumar, R. Bhutani and N. Awasthi, "Toothpaste Lava from the Barren Island Volcano (Andaman Sea)," Journal of Volcanology and Geothermal Research, Vol. 202, No. 1-2, 2011, pp. 73-82. doi:10.1016/j.jvolgeores.2011.01.006

[5] L. J. Applegarth, H. Pinkerton, M. R. James and S. Calvari, "Lava Flow Superposition: The Reactivation of Flow Units in Compound 'a'ā Flows," Journal of Volcanology and Geothermal Research, Vol. 194, No. 4, 2010, pp. 100-106. doi:10.1016/j.jvolgeores.2010.05.001

[6] L. J. Applegarth, H. Pinkerton, M. R. James and S. Calvari, "Morphological Complexities and Hazards during the Emplacement of Channel-Fed 'a'à Lava Flow Fields: A Study of the 2001 Lower Flow Field on Etna," Bulletin of Volcanology, Vol. 72, No. 6, 2010, pp. 641-656. doi:10.1007/s00445-010-0351-1

[7] H. El Hachimi, N. Youbi, J. Madeira, L. Martins, A. Marzoli, H. Bertrand, G. Bellieni, S. Callegaro, J. Mata, J. M. Munhá, F. Medina, A. Mahmoudi, K. M. Bensalah, B.M. Abbou, "Morphologies and Emplacement Mechanisms of the Lava Flows of the Central Atlantic Magmatic Province (CAMP) of Morocco," Proceedings of the II Central \& North Atlantic Conjugate Margins Conference, Morocco, 29 September-1 October 2010, pp. 96100.

[8] C. E. Suh, S. A. Stansfield, R. S. J Sparks, M. S. Njome, M. N. Wantim and G. G. J. Ernst, "Morphology and Structure of the 1999 Lava Flows at Mount Cameroon Volcano (West Africa) and their Bearing on the Emplacement Dynamics of Volume-Limited Flows," Geological Magazine, 2010, pp. 1-13.

[9] D. Takagi and H. E. Huppert, "Initial Advance of Long Lava Flows in Open Channels," Journal of Volcanology and Geothermal Research, Vol. 195, No. 2-4, 2010, pp. 121-126. doi:10.1016/j.jvolgeores.2010.06.011

[10] R. J. Brown, S. Blake, N. R. Bondre, V. M. Phadnis and S. Self, "'a'ā Lava Flows in the Deccan Volcanic Province, India, and their Significance for the Nature of Continental Flood Basalt Eruptions," Bulletin of Volcanology, Vol. 73, No. 6, 2011, pp. 737-752. doi:10.1007/s00445-011-0450-7

[11] M. N. Wantim, C. E. Suh, G. G. J. Ernst, M. Kervyn and 
P. Jacobs, "Characteristics of the 2000 Fissure Eruption and Lava Flow Fields at Mount Cameroon Volcano, West Africa: A Combined Field Mapping and Remote Sensing Approach," Geological Journal, Vol. 46, No. 4, 2011, pp. 344-363. doi:10.1002/gj.1277

[12] S. W. Anderson, S. E. Smrekar and E. R. Stofan, "Tumulus Development on Lava Flows: Insights from Observations of Active Tumuli and Analysis of Formation Models," Bulletin of Volcanology, Vol. 74, No. 4, 2012, pp. 931-946. doi:10.1007/s00445-012-0576-2

[13] J. E. Bailey, A. J. L. Harris, J. Dehn, S. Calvari and S. K. Rowland, "The Changing Morphology of an Open Channel on Mount Etna," Bulletin of Volcanology, Vol. 68, No. 6, 2006, pp. 497-515. doi:10.1007/s00445-005-0025-6

[14] A. J. L. Harris, L. P. Flynn, O. Matias, W. I. Rose and J. Cornejo, "The Evolution of An Active Silicic Lava Flow Field: An ETM+ Perspective," Journal of Volcanology and Geothermal Research, Vol. 135, No. 1-2, 2004, pp. 147-168. doi:10.1016/j.jvolgeores.2003.12.011

[15] A. J. L. Harris, M. Favalli, M. Francesco and C. W. Hamilton, "Construction Dynamics of A Lava Channel," Bulletin of Volcanology, Vol. 71, No. 4, 2009, pp. 459-474. doi:10.1007/s00445-008-0238-6

[16] M. Favalli, A. J. L. Harris, A. Fornaciai, M. T. Pareschi and F. Mazzarini, "The Distal Segment of Etna's 2001 Basaltic Lava Flow," Bulletin of Volcanology, Vol. 72, No. 4, 2010, pp. 119-127. doi:10.1007/s00445-009-0300-Z

[17] M. R. James, L. J. Applegarth and H. Pinkerton, "Lava Channel Roofing, Overflows, Breaches and Switching: Insights from the 2008-2009 Eruption of Mt. Etna," Bulletin of Volcanology, Vol. 74, No. 1, 2012, pp. 107-117. doi:10.1007/s00445-011-0513-9

[18] A. J. L. Harris and S. K. Rowland, "FLOWGO: A Kinematic Thermo-Rheological Model for Lava Flowing in A Channel," Bulletin of Volcanology, Vol. 63, No. 1, 2001, pp. 20-44. doi:10.1007/s004450000120

[19] G. M. Crisci, S. Di Gregorio, R. Rongo, M. Scarpelli, W. Spataro and S. Calvari, "Revisiting the 1669 Etnean Eruptive Crisis Using Cellular Automata Model and Implications for Volcanic Hazard in the Catania Area," Journal of Volcanology and Geothermal Research, Vol. 123, No. 1-2, 2003, pp. 211-230. doi:10.1016/S0377-0273(03)00037-4

[20] G. M. Crisci, R. Rongo, S. Di Gregorio and W. Spataro, "The Simulation Model Sciara: The 1991 and 2001 Lava Flows at Mount Etna," Journal of Volcanology and Geothermal Research, Vol. 132, No. 2-3, 2004, pp. 253-267. doi:10.1016/S0377-0273(03)00349-4

[21] G. M. Crisci, G. Iovine, S. Di Gregorio and V. Lupiano, "Lava-flow Hazard on the SE Flank of Mt. Etna (Southern Italy)," Journal of Volcanology and Geothermal Research, Vol. 177, No. 4, 2008, pp. 778-796. doi:10.1016/j.jvolgeores.2008.01.041

[22] A. Ciraudo, C. Del Negro, A. Herault and A. Vicari, "Advances in Modelling Methods for Lava Flows Simulation," Communications to SIMAI Congress, Vol. 2, No. 4, 2007, pp. 1827-9015.

[23] A. Vicari, H. Alexis, C. Del Negro, M. Coltelli, M.
Marsella and C. Proietti, "Modelling of the 2001 Lava Flow at Etna Volcano by a Cellular Automata Approach," Environmental Modelling and Software, Vol. 22, No. 4, 2007, pp. 1465-1471. doi:10.1016/j.envsoft.2006.10.005

[24] Ruxton, "Report on Volcanic Eruptions on the Cameroons Mountain," 1922.

[25] C. E. Suh, R. S. J. Sparks, J. G. Fitton, S. N. Ayonghe, C. Annen, R. Nana and A. Luckman, "The 1999 and 2000 Eruptions of Mount Cameroon: Eruption Behaviour and Petrochemistry of Lava," Bulletin of Volcanology, Vol. 65, No. 4, 2003, pp. 267-281. doi:10.1007/s00445-002-0257-7

[26] S. Calvari and H. Pinkerton, "Formation of Lava Tubes and Extensive Flow Field during the 1991-93 Eruption of Mount Etna," Journal of Geophysical Research, Vol. 103, No. B11, 1998, pp. 27291-27302. doi:10.1029/97JB03388

[27] C. R. J. Kilburn and R. M. C. Lopes, "The Growth of 'a'ā Lava Flow Fields on Mount Etna, Sicily," Journal of Geophysical Research, Vol. 93, No. B12, 1988, pp. 759772. doi:10.1029/JB093iB12p14759

[28] A. Felpeto, V. Arana, R. Ortiz, M. Astiz and A. Garcia, "Assessment and Modelling of Lava Flow Hazard on Lanzarote (Canary Islands)," Natural Hazards, Vol. 23, No. 2-3, 2001, pp. 247-257. doi:10.1023/A:1011112330766

[29] R. A. Duraiswami, N. R. Bondre, G. Dole, V. M. Phadnis and V. S. Kale, "Tumuli and Associated Features from the Western Deccan Volcanic Province, India," Bulletin of Volcanology, Vol. 63, No. 7, 2001, pp. 435-442. doi:10.1007/s004450100160

[30] C. R. J. Kilburn and R. M. C. Lopes, "General Patterns of Flow Field Growth: 'a'ā and Blocky Lavas," Journal of Geophysical Research, Vol. 96, No. B12, 1991, pp. 721732. doi:10.1029/91JB01924

[31] J. E. Guest, A. M. Duncan, E. R. Stofan and S. W. Anderson, "Effect of Slope on Development of Pahoehoe Flow Fields: Evidence from Mount Etna," Journal of Volcanology and Geothermal Research, Vol. 219, No. 11, 2012, pp. 52-62. doi:10.1016/j.jvolgeores.2012.01.006

[32] C. R. J. Kilburn, "Lava Flows and Flow Fields," In: H. Sigurdsson, Ed., Encyclopaedia of Volcanoes, Academic Press, San Diego, 2000, pp. 291-305.

[33] G. P. L. Walker, "Structure and Origin by Injection of Lava under Surface Crust, of Tumuli, 'Lava Rises', 'Lava-Rise Pits', and 'Lava-Inflation Clefts' in Hawaii,” Bulletin of Volcanology, Vol. 53, No. 7, 1991, pp. 546-558. doi:10.1007/BF00298155

[34] J. G. Fitton, C. R. J Kilburn, M. F. Thirlwall and D. J. Hughes, "1982 Eruption of Mount Cameroon, West Africa," Nature, Vol. 306, No. 5941, 1983, pp. 327-332. doi: $10.1038 / 306327 \mathrm{a} 0$

[35] B. Deruelle, J. N'ni and R. Kambou, "Mount Cameroon: An Active Volcano of the Cameroon Line," Journal of African Earth Sciences, Vol. 6, No. 2, 1987, pp. 197-214.

[36] B. Ateba and N. Ntepe, "Post-Eruptive Activity of Mount Cameroon (Cameroon) West Africa: A Statistical Analysis," Journal of Volcanology and Geothermal Research, 
Vol. 79, No. 1-2, 1997, pp. 25-45. doi:10.1016/S0377-0273(97)00022-X

[37] R. U. Ubangoh, B. Ateba, S. N. Ayonghe and G. E. Ekodeck, "Earthquake Swarms of Mount Cameroon, West Africa," Journal of African Earth Sciences, Vol. 24, No. 4, 1997, pp. 413-424. doi:10.1016/S0899-5362(97)00072-9

[38] C. E. Suh, S. N. Ayonghe and E. S. Njumbe, "Neotectonic Earth Movement Related to the 1999 Eruption of Cameroon Mountain, West Africa," Episodes, Vol. 24, No. 1, 2001, pp. 9-12.

[39] C. E. Suh, J. F. Luhr and M. S. Njome, "Olivine-Hosted Glass Inclusions from Scoriae Erupted in 1954-2000 at Mount Cameroon Volcano, West Africa," Journal of Volcanology and Geothermal Research, Vol. 169, No. 1-2, 2008, pp. 1-33. doi:10.1016/j.jvolgeores.2007.07.004

[40] B. Ateba, C. Dorbath, L. Dorbath, N. Ntepe, M. Frogneux, F. T. Aka, J. V. Hell, J. C. Delmond and D. Manguelle, "Eruptive and Earthquake Activities Related to the 2000 Eruption of Mount Cameroon Volcano (West Africa)," Journal of Volcanology and Geothermal Research, Vol. 179, No. 3-4, 2009, pp. 206-216. doi:10.1016/j.jvolgeores.2008.11.021

[41] K. Bonne, M. Kervyn, L. Cascones, S. Njome, E. V. Ranst, E. Suh, S. Ayonghe, P. Jacobs and G. Ernst, "A New Approach to Assess Long-Term Lava Flow Hazard and Risk Using GIS and Low-Cost Remote Sensing: the Case of Mount Cameroon, West Africa," International Journal of Remote Sensing, Vol. 29, No. 22, 2008, pp. 6537-6562. doi:10.1080/01431160802167873

[42] P. Thierry, L. Stieltjes, E. Kouokam, P. Nguéya and P. M. Salley, "Multi-Hazard Risk Mapping and Assessment on An Active Volcano: The GRINP Project at Mount Cameroon," Natural Hazards, Vol. 45, No. 3, 2008, pp. 429456. doi:10.1007/s11069-007-9177-3

[43] M. Favalli, S. Tarquini, P. Papale, A. Fornaciai and E. Boschi, "Lava Flow Hazard and Risk at Mt. Cameroon Volcano," Bulletin of Volcanology, Vol. 74, No. 2, 2012, pp. 423-439. doi:10.1007/s00445-011-0540-6

[44] P. Lipman and N. G. Banks, “'a'ā Flow Dynamics, Mauna Loa.” In: R. W. Decker, T. L. Wright and P. H. Stauffer, Eds., Volcanism in Hawaii, US Geological Survey Professional Paper, Vol. 1350, No. 2, 1987, pp. 1527-1567.

[45] L. Lodato, L. Spampinato, A. J. L. Harris, S. Calvari, J. Dehn and M. Patrick, "The Morphology and Evolution of the Stromboli 2002-2003 Lava Flow Field: An Example of A Basaltic Flow Field Emplaced on A Steep Slope," Bulletin of Volcanology, Vol. 69, No. 6, 2007, pp. 661697. doi:10.1007/s00445-006-0101-6

[46] K. Hon, J. Kauahikaua, R. Denlinger and K. Mackay, "Emplacement and Inflation of Pahoehoe Sheet Flows: Observations and Measurements of Active Lava Flows on Kilauea Volcano, Hawaii," Geological Society of America Bulletin, Vol. 106, No. 3, 1994, pp. 351-370. doi:10.1130/0016-7606(1994)106<0351:EAIOPS $>2.3 . C$ $\underline{\mathrm{O} ; 2}$

[47] J. G. Fitton and H. M. Dunlop, "The Cameroon Line, West Africa, and Its Bearing on the Origin of Oceanic and Continental Alkali Basalt," Earth and Planetary Sci- ence Letters, Vol. 72, No. 1, 1985, pp. 23-28. doi:10.1016/0012-821X(85)90114-1

[48] C. Moreau, J-M. Regnoult, B. Deruelle and B. Robineau, "A New Tectonic Model for the Cameroon Line, Central Africa," Tectonophysics, Vol. 139, 1987, pp. 317-334.

[49] A. N. Halliday, A. P. Dickin, A. E. Fallick and J. G. Fitton, "Mantle Dynamics: $\mathrm{A} \mathrm{Nd}, \mathrm{Sr}, \mathrm{Pb}$ and $\mathrm{O}$ isotopic study of the Cameroon Line Volcanic Chain," Journal of Petrology, Vol. 29, No. 1, 1988, pp. 181-211. doi:10.1093/petrology/29.1.181

[50] C. T. Tabod, J. D. Fairhead, G. W. Stuart, B. Ateba and N. Ntepe, "Seismicity of the Cameroon Volcanic Line, 19821990," Tectonophysics, Vol. 212, No. 3-4, 1992, pp. 303320. doi:10.1016/0040-1951(92)90297-J

[51] F. T. Aka, K. Nagao, M. Kusakabe, H. Sumino, G. Tanyileke, B. Ateba and J. Hell, "Symmetrical Helium Isotope Distribution on the Cameroon Volcanic Line, West Africa," Chemical Geology, Vol. 203, No. 3-4, 2004, pp. 205-223. doi:10.1016/j.chemgeo.2003.10.003

[52] B. Deruelle, I. Ngounouno and D. Demaiffe, "The 'Cameroon Hot Line' (CHL): A Unique Example of Active Alkaline Intraplate Structure in both Oceanic and Continental Lithospheres," Comptes Rendus Geoscience, Vol. 339, No. 9, 2007, pp. 589-600. doi:10.1016/j.crte.2007.07.007

[53] L. Mathieu, M. Kervyn and G. G. J. Ernst, "Field Evidence for Flank Instability, Basal Spreading and Volcano-Tectonic Interactions at Mt. Cameroon, West Africa," Bulletin of Volcanology, Vol. 73, No. 7, 2011, pp. 851-867. doi:10.1007/s00445-011-0458-Z

[54] C. Nkoumbou, B. Deruelle and D. Velde, "Petrology of Mt. Etinde Nephelinite Series," Journal of Petrology, Vol. 36, No. 2, 1995, pp. 373-393. doi:10.1093/petrology/36.2.373

[55] G. Hulme, "The Interpretation of Lava Flow Morphology," Geophysical Journal Royal Astronomical Society, Vol. 39, No. 2, 1974, pp. 361-383. doi:10.1111/j.1365-246X.1974.tb05460.x

[56] H. J. Moore, "Preliminary Estimates of the Rheological Properties of 1984 Mauna Loa Lava.” In: R. W. Decker, T. L. Wright, P. H. Stauffer, Eds., Volcanism in Hawaii, United States Government Printing Office, Washington DC, 1987, pp. 1569-1588.

[57] A. J. L. Harris, A. L. Butterworth, R. W. Carlton, I. Downey, P. Miller, P. Navarro and D. A. Rothery, "LowCost Volcano Surveillance from Space: Case Studies from Etna, Rafla, Cerro Negro, Fogo, Lascar and Erebus," Bulletin of Volcanology, Vol. 59, No. 1, 1997, pp. 49-64. doi:10.1007/s004450050174

[58] Y. Bottinga and D. F. Weill, "Densities of Liquid Silicate Systems Calculated from Partial Molar Volumes of Oxide Components," American Journal of Science, Vol. 269, No. 2, 1970, pp. 169-182. doi:10.2475/ajs.269.2.169

[59] N. F. Stevens, G. Wadge and J. B. Murray, "Lava Flow Volume and Morphology from Digitised Contour Maps: A Case Study at Mount Etna, Sicily," Geomorphology, Vol. 28, No. 3-4, 1999, pp. 251-261. doi:10.1016/S0169-555X(98)00115-9 
[60] M. Polacci and P. Papale, "The Evolution of Lava Flows from Ephemeral Vents at Mount Etna: Insights from Vesicle Distribution and Morphological Studies," Journal of Volcanology and Geothermal Research, Vol. 76, No. 1-2, 1997, pp. 1-17. doi:10.1016/S0377-0273(96)00070-4

[61] J. A. Naranjo, R. S. J. Sparks, M. V. Stasiuk, H. Moreno and G. J. Ablay, "Morphological, Structural and Textural Variations in the 1988-1990 Andesite Lava of Lonquimay Volcano, Chile," Geological Magazine, Vol. 129, No. 6, 1992, pp. 657-678. doi:10.1017/S0016756800008426

[62] M. J. Kennish and R. A. Lutz, "Morphology and Distribution of Lava Flows on Mid-Ocean Ridges: A Review," Earth Science Reviews, Vol. 43, No. 3-4, 1998, pp. 63-90. doi:10.1016/S0012-8252(98)00006-3

[63] S. Calvari and H. Pinkerton, "Lava Tube Morphology on Etna and Evidence for Lava Flow Emplacement Mechanisms," Journal of Volcanology and Geothermal Research, Vol. 90, No. 3-4, 1999, pp. 263-280. doi:10.1016/S0377-0273(99)00024-4

[64] M. Dragoni and A. Piombo, "Thermoelastic Deformation Associated with A Lava Tube," Bulletin of Volcanology, Vol. 71, No. 4, 2009, pp. 409-418. doi:10.1007/s00445-008-0248-4

[65] R. S. J. Sparks, H. Pinkerton and G. Hulme, "Classification and Formation of Lava Levees on Mount Etna, Sicily," Geology, Vol. 4, No. 5, 1976, pp. 269-271. doi:10.1130/0091-7613(1976)4<269:CAFOLL $>2.0 . C O ; 2$

[66] F. Quareni, A. Tallarico and M. Dragoni, "Modelling of the Steady-State Temperature Field in Lava Flow Levees," Journal of Volcanology and Geothermal Research, Vol. 132, No. 2-3, 2004, pp. 241-251.
doi:10.1016/S0377-0273(03)00348-2

[67] G. A. Macdonald, "Pahoehoe, 'a'ā and Block Lava," American Journal of Science, Vol. 251, No. 3, 1953, pp. 169-191. doi:10.2475/ajs.251.3.169

[68] C. R. J. Kilburn, "Fracturing as a Quantitative Indicator of Lava Flow Dynamics," Journal of Volcanology and Geothermal Research, Vol. 132, No. 2-3, 2004, pp. 209224. doi:10.1016/S0377-0273(03)00346-9

[69] J. E. Guest and E. R. Stofan, "The Significance of SlabCrusted Lava Flows for Understanding Controls on Flow Emplacement at Mount Etna, Sicily," Journal of Volcanology and Geothermal Research, Vol. 142, No. 3-4, 2006, pp. 193-205. doi:10.1016/j.jvolgeores.2004.09.003

[70] P. Francis and C. Oppenheimer, "Volcanoes," 2nd Edition, Oxford University Press, Oxford, 2004.

[71] M. J. Rossi and A. Gudmundsson, "The Morphology and Formation of Flow-Lobe Tumuli on Icelandic Shield Volcanoes," Journal of Volcanology and Geothermal Research, Vol. 72, No. 3-4, 1996, pp. 291-308. doi:10.1016/0377-0273(96)00014-5

[72] A. M. Duncan, J. E. Guest, E. R. Stofan, S. W. Anderson, H. Pinkerton and S. Calvari, "Development of Tumuli in the Medial Portion of the 1983 'a'ā Flow field, Mount Etna, Sicily," Journal of Volcanology and Geothermal Research, Vol. 132, No. 2-3, 2004, pp. 173-187. doi:10.1016/S0377-0273(03)00344-5

[73] R. Greeley, "The Role of Lava Tubes in Hawaiian Volcanoes.” In: R. W. Decker, T. L. Wright, P. H Stauffer, Eds., Volcanism in Hawaii, United States Government Printing Office, Washington, 1993, pp. 1589-1602. 